\title{
VOICE AND EXIT AS ACCOUNTABILITY MECHANISMS: CAN FOOT-VOTING BE MADE SAFE FOR THE CHINESE COMMUNIST PARTY?
}

\author{
Roderick M. Hills, Jr.* \& Shitong Qiao ${ }^{* * *}$
}

\begin{abstract}
According to Albert O. Hirschman's famous dichotomy, citizens can express their preferences with their "voice" (by voting with ballots to elect better representatives) or by "exit" (by voting with their feet to choose better places to live). Suppose, however, that ballot-voting is ineffective: Can exit not merely aid but also replace voice? Using the People's Republic of China, a party state without elective democracy as a case study, we argue that exit is not a substitute for, but rather a complement to, voice. China's bureaucratic promotion system plays the same role that local elections do in the United States, promoting or replacing local officials based on their performance in office. In either regime, however, it is costly for local voters (in the United States) or the Chinese Communist Party (in China) to monitor and assess local officials. Attention to foot-voting in the legal design of local government can help reduce these costs. By evaluating cadres who run the lower levels of China's local governments on the basis of how successfully they attract mobile households, the central CCP authorities could reduce the costs of monitoring these local officials and thereby reproduce, by bureaucratic means, some of the benefits of

* William T. Comfort III Professor of Law, New York University Law School. For their comments and discussions, the authors gratefully acknowledge Daryl Levinson, Robert Ellickson, Henry Hansmann, Zhang Taisu, Tian Lei, Ma Xiang, Zhou Yucheng, and Susan Rose-Ackerman. The authors also thank Sun Weixiao, Hu Haifan, Ye Xiangwen, and Qi Yue for their excellent research assistance. Shitong Qiao acknowledges generous support from the University of Hong Kong Seed Funding Programme for Basic Research (Project Code: 201411159056), and Roderick Hills acknowledges generous support from the Filomen D'Agostino Research Fund at NYU School of Law.

*** Assistant Professor of Law, University of Hong Kong; JSD, Yale.
\end{abstract}


electoral democracy. The Party can most cheaply measure success in attracting foot-voters by evaluating cadres primarily on the basis of local land values which, because they are a product of foot-voters' decisions about where to live, function like ballots insofar as they reflect the popularity of local cadres' policy decisions with mobile Chinese households. For foot-voting to improve governmental accountability, however, the Chinese system of local government law requires some basic but politically feasible reforms - in particular, the introduction of a local property tax system, the creation of a federated city system that grants power and autonomy to sub-city units, and the liberalization of China's household registration system to make the population fully mobile across different jurisdictions.

\section{INTRODUCTION}

It is a familiar idea that citizens can express their preferences either by voting with ballots or voting with their feet. When citizens vote with ballots, they collectively select policies or candidates governing the jurisdiction in which they reside. When they vote with their feet, citizens individually migrate to jurisdictions governed by their preferred policies or officials. Using Albert O. Hirschman's famous dichotomy, ballot-voting is described as the use of "voice," while foot-voting is described as "exit." But the two mechanisms may be seen as simply different ways for individuals to make collective choices - with ballots, of people and policies; with feet, of places.

The existence of these parallel mechanisms for revealing citizens' preferences suggests that exit might be a substitute as well as a complement for voice. Suppose that local elections are impractical or ineffective. Could one achieve some or all of the accountability that such elections are intended to achieve simply by giving citizens the power to shop around for a local government that suits their desires? Could foot-voting not merely aid but also replace ballot-voting?

The People's Republic of China presents an opportunity to investigate this question of whether foot-voting can be a substitute for ballot-voting. Although the ideology of the Chinese Communist Party ("CCP") permits "intra-party democracy" (dangnei minzhu, 党内 民主), actual voting on rival candidates at the local level and even

1. See Albert O. HiRschman, EXIT, VOICE, AND LOYALTY: RESPONSES TO DECLINE IN FIRMS, ORGANIZATIONS, AND STATES 4-7 (1970). 
within the Communist Party is strikingly rare in China. ${ }^{2}$ In general, "cadres"-a term that, for the purposes of this article, refers to CCP members seeking or holding public office-are assessed and promoted by central CCP authorities without the intervention of any popular election. The CCP's ideology of democratic centralism, in other words, is more central than democratic, making any robust system of citizen voice difficult to install as long as the CCP is in power.

At the same time, CCP leaders are aware of the need to anticipate and address public complaints about air pollution, corruption, access to jobs and education, police brutality, and other failures of governance. ${ }^{3}$ If there were an accurate way to measure public demand for various local public goods that did not pose a political risk to continued rule by the CCP, the CCP would have every reason to embrace the mechanism. Foot-voting by mobile Chinese citizens might be precisely such a mechanism by which (to borrow $\mathrm{Yu}$ Keping's phrase) democracy might be made safe for the Communist Party. ${ }^{4}$

We provide some cautiously optimistic arguments in favor of exit as a way to improve the accountability of local officials to Chinese citizens. The basic idea is that the CCP cadres who run the lower levels of China's local governments-in particular, the urban districts and counties rather than the provinces and prefectural-level cities-could be evaluated based on how successfully they compete with each other for mobile households choosing a jurisdiction in which to live. Such success would theoretically be reflected in the

2. For brief summaries of the debate over the seriousness of intra-party democracy in China, see Joseph Fewsmith, Inner-Party Democracy: Development and Limitations, CHINA LEADERSHIP MONITOR, Winter 2010, at 4-9. For a full-scale defense of intra-party democracy from an insider, see YU KEPING, DEMOCRACY IS A GOOD THING: ESSAYS ON POLITICS, SOCIETY, AND CULTURE IN CONTEMPORARY CHINA 3-5 (2009). For a description of various efforts to hold township elections to decide on cadre promotions, see JOSEPH FEWSMITH, THE LOGIC AND LIMITS OF POLITICAL REFORM IN CHINA (2012).

3. See, e.g., Francis FUKUYAMA, POLITICAL ORder AND POLITICAL DECAY 380 (2014) (noting that the CCP is responsive to the demands of "various actors in Chinese society, including local communities); Bruce Gilley, Legitimacy and Institutional Change: the Case of China, 41 CoMP. POL. STUD. 259, 264-65 (2008) (citing studies that show how the CCP has responded to demands for more efficient local rule); Stephen White, Economic Performance and Communist Legitimacy, 38 WORLD POL. 462, 472 (1986) (explaining CCP electoral practices).

4. See Yu Keping (俞可平), Zhengzhi Gaige de Heli Lujing (政治改革的合理 路径), CHINA IN PERSPECTIVE (Feb. 25, 2012), http://www.chinainperspective.com/ ArtShow.aspx?AID=14389. 
price of land, a price that would reflect ("capitalize") local cadres' decisions about regulations, expenditures, and revenue-raising. Through the magic of such capitalization, central Party officials could evaluate which cadres were really enhancing social welfare by satisfying their citizens' preferences for public goods instead of wasting money on showy "face projects" ${ }^{\text {" }}$ and the pollution-generating industry (the costs of which exceeds the benefits). In effect, foot-voting could instigate competition among cadres for migrants to bid up the value of their jurisdiction's land by attracting the "votes" of foot-voters, a competition that might be a form of "intra-party democracy" (or, at least, intra-party competition) safe enough for the CCP to adopt.

We caution that our defense of exit is contingent on the CCP's adoption of some system to give local cadres proper incentives and tools for competing with each other for mobile households. At the most general theoretical level, exit cannot be a substitute for voice unless some mechanism gives subnational officials an incentive to care about attracting mobile citizens. In liberal democracies, local elections provide such a mechanism. In a Leninist system of democratic centralism, the official criteria for bureaucratic promotion play the role of elections. Rather than focusing on local GDP, local job creation, or local revenue generation, central CCP authorities ought to focus on local land prices and on promoting cadres who improve the value of land by attracting more buyers. To facilitate citizens' foot-voting and inter-jurisdictional competition, we urge the introduction of a property tax system in Chinese cities-a system which could become the monetary voice of China's mobile citizenry. We also urge the building of a federated city system that grants power and autonomy to sub-city units of proper size, and we recommend the further reform of China's household registration (hukou, 户口) system to make the population fully mobile among different jurisdictions.

Beyond these specific suggestions for reform in China, this article also suggests a relationship between exit and voice in which one is not a substitute for, but rather a complement to, the other. Without voice, or a mechanism analogous to voice like bureaucratic promotion criteria, exit cannot function well as a system of

5. In Chinese, “face projects" or "mianzi gongcheng" (面子工程) refer to infrastructures that are showy but not useful. See, e.g., 面子工程触目惊心, 有多少 浪费可以重来 [How Much Could We Waste On Face Projects], http://www.xinhuanet.com/fortune/by18.htm (last visited Aug. 2, 2016). 
accountability to mobile households, because subnational officials, angling for promotion, have no reason a priori to care about maximizing the value of local real estate. Our specific suggested reforms are an effort to enlist the CCP's bureaucratic promotion system to do the work that citizen voice performs in the United States and other liberal democracies. Whether that bureaucratic promotion system can bear such weight is an open question. We provide only an abstract theoretical case that foot-voting can be made safe for the CCP if the CCP makes Chinese local governments responsive to foot-voters.

Part I of this Article addresses the paradoxical nature of the CCP's democratic centralism, a fundamental principle of the Chinese party state. Part II compares foot-voting in liberal democracies and authoritarian regimes and argues that the bureaucratic promotion criteria in China are the necessary complement to exit-based control of local officials just as local elections are necessary for foot-voting in the United States. Part III proposes using land values as the main criterion in the CCP's cadre evaluation, because they are the best proxy for a foot-voter's choices. Part IV defends three feasible institutional reforms, namely property tax, federated cities, and household registration ( hukou, 户口) reform, to improve government accountability through citizen mobility in China.

\section{Lenin's NightMARE: HOW CAN THE CENTER CONTROL THE CADRES IN A REGIME OF "DEMOCRATIC CENTRALISM"?}

The benefits of exit depend on the costs of voice. If voters, aided by a vigorous press and competitive political parties, could easily choose officials who would truly enact those voters' preferred policies, then the relative benefits of facilitating citizen choice through migration would be reduced. Why rely on citizen mobility when electoral accountability can accomplish the same end without the hassle of migration? The answer is that sometimes there are impediments to effective voice. Local voters, for instance, might be rationally ignorant about political decisions because their vote has a minuscule chance of affecting the outcome, and therefore, be apathetic or ignorant in casting their ballots. Local governments might also be dominated by a single political party or interest that suppresses genuine electoral choices. Confronted by such impediments to effective voice, one might try instead to elicit popular preferences through exit. 
In China, citizens can use both voice and exit to control the government, but access to both is limited by ideological and legal constraints. Part IV discusses the institutional limits on exit. This Part describes both the power of, and limits on, citizens' voice under the principle of "democratic centralism." These limits on citizen voice can be a substantial impediment to the CCP's effective monitoring and control of its cadres, suggesting a need for voice to be supplemented by exit.

\section{A. An Overview of Democratic Centralism's Limits on "Voice"}

At the heart of the CCP's ideology is a contradictory attitude towards popular participation in government, captured by the phrase “democratic centralism" (minzhu jizhong zhi 民主集中制). Promoted by Lenin as a principle for governing the Bolshevik Party and eventually the Soviet state, democratic centralism has also been adopted as a governing principle of the CCP. ${ }^{6}$ Democratic centralism suggests a contradiction, because it simultaneously encourages and limits popular criticism of the government. ${ }^{7}$ On one hand, the idea of socialist democracy requires the $\mathrm{CCP}$ to "connect to the people closely" by keeping a close eye on popular opinion, soliciting popular views about the government's performance and responding to those views in the CCP's policy decisions. On the other hand, the actual governmental decisions must be "centralized," meaning that they must be made by the Party leadership, not by the people themselves

6. On the origins of democratic centralism in the Bolshevik Party, see Michael WALleR, DEMOCRATIC CenTRALisM: AN HistoriCAL COMMENTARY 31-32 (1981). For Lenin's original statement of democratic centralism, see Vladimir Lenin, Freedom to Criticise and Unity of Action, in LENIN COLLECTED WORKS 442, 442-43 (1965), https://www.marxists.org/archive/lenin/works/1906/ may/20c.htm; see also Vladimir Lenin, Report on the Unity Congress of the R.S.D.L.P. (1906), http://intersci.ss.uci.edu/wiki/eBooks/Russia/BOOKS/Lenin/ The $\% 20$ Congress $\% 20$ Summed $\% 20 \mathrm{Up} \% 201906 \% 20 \% 20 \mathrm{Lenin}$.pdf.

Lenin faced considerable internal and international opposition to his principle of democratic centralism, with Rosa Luxemburg's 1904 article being the most eloquent and well-known example. See Rosa Luxemburg, Organizational Questions of the Russian Social Democracy (1904), https://www.marxists.org/ archive/luxemburg/1904/questions-rsd/. On the adoption of democratic centralism by the CCP in 1927, see Stephen C. Angle, Decent Democratic Centralism, 33 POL. THEORY 518, 524-25 (2005) (citing ANTHONY SAICH, THE RISE TO POWER OF THE ChINESE COMMUNIST PARTY: DOCUMENTS AND ANALYSIS 259, 806 (1996)).

7. For a succinct account of the tensions implicit in the idea of democratic centralism, see Gang Lin, Leadership Transition, Intra-Party Democracy, and Institution Building in China, 44 ASIAN SUR. 255, 273 (2004). 
or their elected representatives. Mao's description of democratic centralism as "contradictory parts of an integrated principle" suggests the delicate balancing act that these two ideas require. ${ }^{8}$ The Party listens to popular opinion in formulating policy, but it is the Party, not majority voting by the people, that makes the ultimate decision based on popular input. ${ }^{9}$

This idea of democratic centralism explains what to an outside observer can seem like a perplexing contradiction. On the one hand, public debate in China is not merely outspoken but raucous. ${ }^{10}$ On the other, any effort to engage in collective action or social mobilization outside of the CCP is quickly and sometimes brutally suppressed. ${ }^{11}$ Consider, for instance, Chinese regulation of online speech. With the rise of the internet and new media platforms, more than 1.3 billion people can now broadcast their individual views. ${ }^{12}$ Far from trying to eliminate such online discussions, the CCP has tolerated or even actively encouraged them. ${ }^{13}$ For example,

8. MaO ZeDONG, On the Correct Handling of Contradictions Among the People, in SeleCted REAdINGS FROM THE WORKS OF MAO TSE-TUNG 432 (1971).

9. Zhang Muliang (张慕良), Minzhu he Jizhong de Zhucong Guanxi shi Zenyang Xingcheng de (民主和集中的主从关系是怎样形成的) [How Did the Subsidiary Relationship between Democracy and Centralization Form.], XUEXI SHIBAO (学习时报) (Oct. 19, 2010), http://www.chinaelections.com/article/ 196/189241.html. See also KenNeTH LiberTHAL, GOVERnING CHINA: From REVOLUTION THROUGH REFORM 193 (2d. Ed. 2004) (noting that the process of democratic centralism involves gathering input from various groups).

10. See, e.g., Ya-Wen Lei, The Political Consequences of the Rise of the Internet: Political Beliefs and Practices of Chinese Netizens, 28 POL. COMM. 291 (2011) (finding that Chinese internet users are more politically opinionated than traditional media users and non-media users); $\mathrm{Li} \mathrm{Qi} \&$ William Wan, China's Constitution Debate Hits a Sensitive Nerve, WASH. POST (June 3, 2013), https://www.washingtonpost.com/news/worldviews/wp/2013/06/03/chinasconstitution-debate-hits-a-sensitive-nerve/?utm_term=.2c7ee71d25a7 (noting the widespread discussion that took place online regarding constitutionalism in China); Felicia Sonmez, Free Speech in China Gets an Unlikely State-Media Backer, WALL ST. J. (Feb. 17, 2016), http://blogs.wsj.com/chinarealtime/ 2016/02/17/free-speech-in-china-gets-an-unlikely-state-media-backer/ (noting the large number of comments and "likes" posted on a Chinese blog post on the subject of internal criticism).

11. Gary King et al., How Censorship in China Allows Government Criticism but Silences Collective Expression, 107 AM. POL. SCI. REV. 1 (2013).

12. Id.

13. See, e.g., Ya-Wen Lei \& Daniel Xiaodan Zhou, Contesting Legality in Authoritarian Contexts: Food Safety, Rule of Law and China's Networked Public Sphere, 49 L. \& SOC'Y REV. 557, 559 (2015) (explaining how, by allowing a certain degree of criticism, "the central government increases its information about, and ability to monitor local Party-states"). 
governmental agencies set up their own Weibo accounts to publicize information, lead discussions, and facilitate citizen reports of cadres' unethical behavior. ${ }^{14}$ As soon as online discussants suggest or assist in collective action, however, they are quickly censored..$^{15}$

A similar distinction seems to guide the CCP's treatment of protests outside of cyberspace. Chinese citizens regularly and effectively engage in "mass incidents" to protest what they regard as

14. See, e.g., Min Jiang, Architecture of Social Management: From $E$-Gov and Gov Weibo to Gov WeChat, CHINA US Focus (Sep. 4, 2015), http://www.chinausfocus.com/political-social-development/architecture-of-socialmanagement-from-e-gov-and-gov-weibo-to-gov-wechat/ (describing how, after the 2011 Wenzhou high-speed train collision resulted in unprecendented public criticism of the Chinese authorities, various government entities opened their own Weibo accounts to bolster their presence on social media); Angela Meng, Beijing Still Struggles to Make Voice Heard Through Sina Weibo, S. CHINA MORNING POST (Mar. 3, 2014, 4:38 AM), http://www.scmp.com/news/china/ article/1438896/beijing-still-struggles-make-voice-heard-through-sina-weibo ("As of October, there were 100,151 government Sina Weibo accounts, 66,830 of which were department ones and 33,321 belonging to individual officials, according to a report by the People Online Public Monitoring Office."); Min Jiang \& Jesper Schlæger, How Weibo Is Changing Local Governance in China, THE DIPLOMAT (Aug. 6, 2014), http://thediplomat.com/2014/08/how-weibo-is-changing-localgovernance-in-china/ (describing how local governments incorporated microblogs into their administrative operation as a form of "social management," a strategy referred to as "occupy weibo"). On the use of the internet to facilitate citizen complaints, see the CENTRAL COMMISSION FOR DISCIPLINE INSPECTION OF THE COMMUNIST PARTY OF CHINA ("CCDI") Supervision Bureau Reporting Website: http://www.12388.gov.cn/; see also "Wo Jubao de Wenti Chachule ma?" Zhongiiwei: Jianjian You Zhuoluo (“我举报的问题查处了朋?"中纪委: 件件有着落) [Any Results on the Case I Reported?" CCDI: Everything is Being Taken Care of], XINHUA WANG (新华网), Feb. 4, 2016, http://news.xinhuanet.com/legal/201602/04/c_128702525.htm; Zhongjiwei "Sifeng" Jiandu Jubao Pingtai Beihou Gushi: Meige Xiansuo Dou You Zhuanren Chuzhi (中紀委"四風"監督舉報平台背后故事：每 個線索都有專人處置) [The Story Behind CCDI'S “Four Trends" Supervision and Reporting Platform: An Exclusive Agent Assigned to Every Lead], RENMIN WANG （人民网)，Feb.5，2016，http://fanfu.people.com.cn/BIG5/n1/2016/0205/c6437128112734.html.

15. See Gary King et al., Reverse-Engineering Censorship in China: Randomized Experimentation and Participant Observation, ScI. (Aug. 22, 2014), http://science.sciencemag.org/content/345/6199/1251722; Gary King et al., supra note 11, at 1 (using statistical analysis of the public's online commentary to show that, "[c]ontrary to previous understandings, posts with negative, even vitriolic, criticism of the state, its leaders, and its policies are not more likely to be censored" but that "censorship program is aimed at curtailing collective action by silencing comments that represent, reinforce, or spur social mobilization, regardless of content"). 
corrupt or harmful governmental policies. ${ }^{16}$ Consider, for instance, the protests of thousands of Chinese residents in 2011 against the siting of paraxylene ("PX") factories near their residences and businesses. Riot police largely left the protestors alone, and local officials mollified them with conciliatory speeches-suffering heckling from the crowds for their pains. ${ }^{17}$ While tolerating such "mass incidents," the CCP has arrested human rights lawyers, labor activists, and feminists who filed lawsuits or organized protests in the name of universal human rights. ${ }^{18}$ These disparate governmental reactions suggest a corresponding theoretical distinction. To petition the CCP for a redress of personal grievances, even angrily, does not offend the idea of "centralism" (jizhongzhi, 集中制). To organize a public lawsuit or demonstration to vindicate the abstract values of human rights or feminism, by contrast, is a direct challenge to the primacy of the CCP over public policy.

\section{B. How Democratic Centralism Weakens the Center}

From the viewpoint of the CCP, these limits on citizens' voice can impose substantial costs on China's governance. By excluding the more institutionalized forms of public input such as lawsuits before

16. See, e.g., Kevin J. O'Brien, Rightful Resistance, 49 WORLD POLITICS 31 (1996) (describing how citizens in China use "rightful resistance" to challenge cadre malfeasance); Tong Yanqi \& Lei, Large-Scale Mass Incidents and Government Responses in China, 1 INT'L J. CHINA STUD. 487 (2010) (describing how social protests in China became increasingly common starting in the $1970 \mathrm{~s}$ and the broad range of issues that can drive protests, including tax concerns, land and labor disputes, environmental issues, and ethnic unrest).

17. See Jonathan Watts, Tens of Thousands Protest Against Chemical Plant in Northern China, THE GuARDIAN (Aug. 14, 2011), https://www.theguardian.com/environment/2011/aug/14/china-protest-against-pxchemical-plant.

18. See Andrew Jacobs \& Chris Buckley, China Targeting Rights Lawyers in a Crackdown, N.Y. TIMES (July 22, 2015), http://www.nytimes.com/2015/ 07/23/world/asia/china-crackdown-human-rights-lawyers.html?_r=0; Sui-Lee Wee, China Arrests Four Labor Activists Amid Crackdown: Lawyers, ReUTERS (Jan. 10, 2016), http://www.reuters.com/article/us-china-rights-idUSKCN0UO05M 20160110; Andrew Jacobs, Taking Feminist Battle to China's Streets, and Landing in Jail, N.Y. TIMES (Apr. 5, 2015), http://www.nytimes.com/2015/ 04/06/world/asia/chinese-womens-rights-activists-fall-afoul-of-officials.html; Didi Kirsten Tatlow, In China, Relatives Await Word on Detained Rights Lawyers After a Year, N.Y. TIMES (July 8, 2016), http://www.nytimes.com/2016/07/09/ world/asia/china-human-rights-lawyers.html. 
independent courts, op-eds from an independent press, or competitive elections of representatives, the "centralizing" side of democratic centralism weakens the constraints on the CCP's cadres, allowing them secretly to defy CCP policies, because neither the CCP leadership nor the disorganized and extra-institutional public is capable of monitoring officials in China's tens of thousands of subprovincial governments. ${ }^{19}$ In this respect, democratic centralism faces a paradoxical dilemma: The more the CCP excludes private citizens from a formal and institutionalized role in controlling local cadres in the name of centralism, the more the local cadres will take the law unto themselves, secretly defying the leadership and thereby undermining the very centralism that the $\mathrm{CCP}$ sought to advance through its tight control of public debate. ${ }^{20}$

The CCP's need for assistance in monitoring its local agents is not unique to China. It is a familiar problem of agency costs that afflicts all large organizations, including congressional supervision of the bureaucracy in the United States. The problem arises from the informational advantages enjoyed by the bureaucracy that implements the central government's general programs. The bureaucracy will typically know much more about the real costs and benefits of the programs it implements, precisely because it implements them. ${ }^{21}$

19. China has 41,636 township-level governments, 2,862 county-level units, 333 prefecture-level units, and 31 provincial-level units (data from 2006). Chenggang Xu, The Fundamental Institutions of China's Reforms and Development, 49 J. ECON. LIT. 1076, 1084 (2011).

20. For rich descriptions of this dilemma relating successful cadre evaluation to rule of law, see Murray Scot Tanner \& Eric Green, Principals and Secret Agents: Central versus Local Control Over Policing and Obstacles to "Rule of Law" in China, 191 CHINA Q. 644 (2007); Carl F. Minzer, Riots and Cover-ups: Counterproductive Control of Local Agents in China, 31 U. PA. J. INT'L L. 53 (2009).

21. For classic accounts of the costs faced by Congress in monitoring the bureaucracy in the United States, see, for example, LAWRENCE C. DODD \& RICHARD L. SCHOTT, CONGRESS AND THE ADMINISTRATIVE STATE 170-73 (1979) (describing the "dispersed and haphazard nature of [Congressional] oversight" of exectutive agencies); James $Q$. Wilson, The Politics of Regulation, in THE POLITICS Of ReGulation 357, 388 (James Q. Wilson ed., 1980) (discussing how regulatory agencies internal operations are largely independent from executive or legistlative scrutiny or control because what the agencies do "has little or no political significance"). For a discussion of oversight in different political systems, see Susan L. SHIRK, THE POLITICAL LOGIC OF ECONOMIC REFORM IN CHINA 57 (1993). As in the United States, informational obstacles to oversight in China can take the form of goal displacement (local bureaucracy implementing the "letter" 
The challenge of supervising local officials poses a dilemma for the CCP's central authorities in which simplicity of evaluation criteria competes with such criteria's completeness. Too little information leads to administrative simplicity, but also to promotions unrelated to cadre success in promoting citizen welfare. Too much information, however, creates opportunities for factions to manipulate the evaluation criteria to favor their own members.

Consider, first, the lemma of over-simplified criteria. The CCP's reliance on GDP growth as the major criterion for evaluating local leaders provides an example of the costs of clear but crude markers of cadre success. ${ }^{22}$ GDP growth is easy to measure and clearly visible to supervising officials, but it is also unrelated to social costs that do not affect economic productivity, including social and environmental costs like traffic jams, air pollution, loss of historic buildings, and destruction of socially cohesive neighborhoods. ${ }^{23}$ The perverse incentives created by promoting cadres on the basis of local GDP is illustrated by the problem of so-called "ghost cities"-often enormous real estate developments promoted by local government officials but inhabited by virtually no residents. The famous ghost city, Ordos, in inner Mongolia, presents a classic case. ${ }^{24}$ One party

but not the "spirit" of the central policy) or data falsification. See Alex Wang, The Search for Sustainable Legitimacy: Environmental Law and Bureaucracy in China, 37 HARV. ENVTL. L. REV. 365, 412 (2013).

22. GDP has indeed been the primary criteria for cadre promotion since the $1990 \mathrm{~s}$. The unspoken rule is that if one does well with respect to the economy, one has the prospect of becoming a central ministry official or joining the Politburo. See Alex L. Wang, The Search for Sustainable Legitimacy: Environmental Law and Bureaucracy in China, 37 HARV. ENVTL. L. REV. 365, 388 (2013) (quoting a central government official in stating that "[e]veryone sees this and knows the deal [that GDP is key]").

23. For a similar suggestion, see Grossly Deceptive Plans, THE ECONOMIST (Jan. 30, 2016), http://www.economist.com/news/china/21689628-chinas-obsessiongdp-targets-threatens-its-economy-grossly-deceptive-plans. On the invisibility of environmental measures in a GDP-centered system, see Wang, supra note 21 , at 388 (quoting a central government official in stating that "[i]n the past, if you spent a lot of money and effort on a wastewater treatment plant, the center would not see it (“中央看不见, (zhongyang kan bu jian)").

24. Jody Rosen, The Colossal Strangeness of China's Most Excellent Tourist City, N.Y. TIMES (Mar. 6, 2015), http://www.nytimes.com/2015/03/06/tmagazine/

ordos-china-tourist-city.html. For a stark photo portrait of Ordos, see Michael Christopher Brown, Ordos, China: A Modern Ghost Town, Time Magazine, http://content.time.com/time/photogallery/0,29307,1975397,00.html. For a less negative assessment, see Eli Bildner, Ordos: A Ghost Town That Isn't, THE ATLANTIC (Apr. 8, 2013), http://www.theatlantic.com/china/archive/2013/04/ordos- 
secretary expanded the city boundary and built numerous roads to the otherwise empty Kangbashi section of the jurisdiction and was later promoted to the provincial-level inner Mongolia government. ${ }^{25}$ He was succeeded by a second party secretary who built a substantial number of skyscrapers and was also promoted.$^{26} \mathrm{~A}$ couple of years after the development had been completed, it stood empty, and the third party secretary was stuck with the ghost city, to which no residents wanted to move. ${ }^{27}$ In short, perverse promotion criteria seems to have induced the local Party leadership to inflate a temporary real estate bubble, creating construction jobs and GDP figures that they could tout as a basis for their promotion, passing on a real estate bomb to their hapless successor.

The problem of over-simplified and incomplete promotion criteria is not unique to the focus on GDP: Any "hard" numerical target will tend to squeeze out consideration of vaguer, less easily measurable criteria. ${ }^{28}$ As a response to the "hard" target of energy usage reduction in the Eleventh Five-Year Plan, for instance, local governments across the country deliberately imposed power outages, denying electricity even to hospitals, schools, traffic lights, and homes. ${ }^{29}$ These outages also prompted private enterprises to use small-scale diesel fuel generators that defeated the pollution-reducing purpose of the hard target. ${ }^{30}$

Switching to the other lemma of more complex and contradictory evaluation criteria, however, does not solve the problem of information costs. The 2009 Experimental Regulation of the CCP Central Organization Department on the Evaluation of Local Leaders and Cadres contains many contradictory goals that merely

a-ghost-town-that-isnt/274776/ (interviewing filmmaker about Ordos documentary showing "how optimistic people are there, and how hopeful they are").

25. Conversation with a Chinese economist who consulted with the Ordos government and whose name needs to be kept anonymous (Nov. 19, 2014).

26. Id.

27. Id.

28. See, e.g., Kevin J. O'Brien \& Lianjiang Li, Selective Policy Implementation in Rural China, 31 CoMP. POLITICS, 167, 173-74 (1999) (because of the difficulty in formulating measurable targets and lack of grass-root participation, local cadres have selectively implemented unpopular policies such as collecting taxes and enforcing birth control over nonquantifiable goals such as employing a democratic work style and respecting villagers' rights).

29. See Wang, supra note 21 , at $421-22$.

30. Id. 
replace the problem of incompleteness with opacity. ${ }^{31}$ Contradictory criteria-say, environmental quality and job growth in polluting industries-are so indeterminate as to be uninformative, inviting each faction in the leadership to promote political allies rather than the truly more successful or qualified cadres. ${ }^{32}$ The identity of the evaluator's faction and the loyalty of the evaluated cadres to their patron can then often play a more important role than actual cadre performance. $^{33}$

Democratic centralism reduces the capacity of the CCP to overcome this dilemma of information costs by reducing citizens' effective monitoring of local officials. ${ }^{34}$ Local residents have an immediate self-interest in efficient infrastructure, cleaner air, honest government, and other local public goods. Their organized, institutional resistance to local cadres could act as "fire alarms," in McCubbins' and Schwartz's familiar phrase, allowing central authorities to economize on their monitoring efforts by focusing on those local jurisdictions where there is a higher risk that local cadres are under-performing. ${ }^{35}$ The $\mathrm{CCP}$ recognizes the advantages of

31. Zhongzubu Yinfa Shishi Difang Lingdaobanzi he Ganbu Kaohe Shixing Banfa (中组部印发实施地方领导班子和平部考核试行办法) [The CCP Organization Department Promulgates Implementation Regulations on the Evaluation of Local Leaders and Cadres), RENMIN WANG (人民网) (July 7, 2006), http://politics. people.com.cn/GB/1027/4567774.html. The 2009 regulation evaluated cadres based on their success in promoting scientific development, including not only GDP but also education, health care, social safety, cultural activities; and sustainable development, carbon emission reduction, environmental protection; and improvement of living standards, and living environment, transportation.

32. See Charles N. Halaby, Bureaucratic Promotion Criteria, 23 ADmIN. SCI. Q. 466, 468 (1978) (discretionary criteria place the control of career opportunities in the hands of administrative officials).

33. Victor Shih et al., Getting Ahead in the Communist Party: Explaining the Advancement of Central Committee Members in China, 106 AM. POL. SCI. REV. 166 (2012). For argument and data suggesting that patronage plays a more ambiguous role in cadres' careers, see Jinghan Zeng, What Matters Most in Selecting Top Chinese Leaders? A Qualitative Comparative Analysis, 18 J. CHIN. POL. SCI. 223 (2013), https://www.researchgate.net/file.PostFile Loader.html?id=56b018c05e9d9700a48b4575\&assetKey=AS\%3A32451259423539 $2 \% 401454381239176$.

34. See Huang Yanzhong, The State of China's State Apparatus, 28 AsIAN PERSPECTIVE 31, 47 (2004) (lower-level officials can fool higher authorities more easily than their counterparts in liberal democracies because of the lack of oversight from citizens).

35. Mathew D. McCubbins \& Thomas Schwartz, Congressional Oversight Overlooked: Police Patrols Versus Fire Alarms, 28 AM. J. POL. SCI. 165, 171-76 (1984). 
citizens' assistance in governance, making use of devices like "democratic appraisal meetings" (minzhu pingyi, 民主评议) in which lower-level cadres anonymously evaluate their superiors as a complement to the usual top-down evaluations. ${ }^{36}$ Democratic centralism, however, weakens these popular controls by limiting the degree to which citizens can organize institutions for independent collective action. Providing unstructured venues for individual citizen complaints-for instance, "appraisal meetings," websites through which lone individuals can report local corruption, or a bureau of letters of complaints ${ }^{37}$ (guojia xinfang $j u$, 国家信访局)-is no substitute for private organizations like newspapers, unions, and organized interest groups. Such civil-society organizations can shoulder the costs of acquiring legal, accounting, and economic expertise and overcome "free rider" problems of public action that isolated individuals cannot or will not bear. ${ }^{38}$

Therefore, the CCP's suspicion of such an institutionalized, collective role for private citizens in the name of democratic centralism is actually decentralizing, not centralizing, because such suspicion empowers local cadres at the expense of the central CCP. In this sense, democratic centralism is self-defeating if it excludes all institutionalized and organized input from the public, demanding citizen passivity or merely individual complaints and petitions rather than active collective engagement.

\section{The Limits AND PROMISE OF FoOT-VOTING IN LIBERAL DEMOCRATIC AND AUTHORITARIAN REGIMES}

If citizen voice is muted by democratic centralism, why not rely on citizen exit? Both voice and exit, after all, are means by which

36. See Maria Edin, State Capacity and Local Agent Control: CCP Cadre Management from a Township Perspective, 173 CHINA Q. 35, 42-43 (2004) (evaluating the cadre management system and arguing that the Chinese party-state has the capacity to be selectively effective in implementing its priority policies).

37. On the Chinese tradition of "letters and calls" by which individual citizens can petition for redress of grievances, see Carl F. Minzner, Xinfang: An Alternative to Formal Chinese Legal Institutions, 42 STAN. J. INT'L L. 103, 176-77 (2006).

38. For the classic account of the costs of collective action, see, for example, MANCUR OLSON, THE LOGIC OF COLLECTIVE ACTION (1965). For an account of how private interest groups overcome such collective action problems, see, for example, LAWRENCE ROTHENBERG, LINKING CITIZENS TO GOVERNMENT: INTEREST GROUP POLITICS AT COMMON CAUSE (1992). 
citizens can select the local officials who govern them. Could foot-voting, therefore, make up for the limits on ballot-voting in China?

As we explain below in Part II(A), exit cannot be a substitute for voice, but it can be a supplement. It is a fallacy to assume that local officials somehow naturally seek to enlarge their tax revenue or any other resources that such migration might produce. ${ }^{39}$ As such, the "market" for local governments cannot arise unless some specific mechanism exists to make local officials care about attracting foot-voters. Incentives to care about foot-voters ordinarily take the form of some sort of "voice"-that is, some mechanism by which local officials' superiors (either local voters or bureaucratic superiors) express an opinion about the performance of local officials by voting on those officials' promotion, demotion, or dismissal. In this sense, the efficacy of exit is always dependent on the efficacy of voice that commands local officials to care about whether their communities are attractive to migrants.

The absence of local elections does not mean that Chinese local officials can never have incentives to cater to foot-voters. We suggest that China's criteria for bureaucratic promotion can be enlisted to induce local cadres to care about households' foot-voting just as local elections are used in the United States to force politicians to campaign on boosting home values. Our argument hinges on an analogy between what William Fischel has called "homevoters"-that is, the property-owning electorate of a local government in the United States-and the CCP's bureaucratic evaluators of cadre performance. ${ }^{40}$ As explained in Part $\mathrm{II}(\mathrm{B})(1)$ below, homevoters in liberal democracies vote against locally-elected officials who do not enact policies attractive to them, thereby inducing local politicians to care about making their jurisdiction attractive to such homebuyers. We explain in Part $\mathrm{II}(\mathrm{B})(2)$ that, in China's system of democratic centralism, the central authorities can play the role of homevoters by withholding promotion from local cadres who fail to make their

39. On the dangers of analogies between public and private organizations that ignore their differing incentives, see Daryl J. Levinson, Making Government Pay: Markets, Politics, and the Allocation of Constitutional Costs, 67 U. CHI. L. REV. 345, 345 (2000) ("[G]overnment does not internalize costs in the same way as a private firm").

40. WILLIAM FISCHEL, THE HOMEVOTER HYPOTHESIS: HOW HOME VALUES INFLUENCE LOCAL GOVERNMENT TAXATION, SCHOOL FINANCE, AND LAND-USE POLICIES 1-16 (2001) [hereinaftrer FISCHEL, HOMEVOTER HYPOTHESIS]. 
jurisdiction attractive to Chinese households, thereby giving cadres an analogous incentive to care about attracting homebuyers.

We will defer until Part III our exposition and defense of a cadre evaluation system rooted in the value of local land-the criterion that we take to be the most faithful measure of success in attracting foot-voters. In this section we make the more basic case that citizen exit can help fix shortcomings of citizen voice only if the authoritarian analogue to local elections-bureaucratic promotion-is revised to make exit relevant to local leaders.

\section{A. The Fallacy of Simple Analogies Between Private Markets and Local Governments}

At least since the work of Charles Tiebout was introduced into the legal academy in the late $1970 \mathrm{~s}$, it has become commonplace for legal scholarship to analogize local governments to private firms that market public goods to "consumer-voters." ${ }^{11}$ Under this view, foot-voting citizens shop among local governmental "firms" looking for the best mix of price and quality in governmental services. ${ }^{42}$ Local officials cater to these mobile "consumer-voters" because those officials want to maximize the value of local real estate. ${ }^{43}$

This firm-government analogy is incomplete, because it ignores the need for a feedback mechanism that induces local officials to care about attracting foot-voters. After all, those officials are not owners of the real estate who are entitled to appropriate the gains in value from attracting buyers. Moreover, powerful ideological

41. Charles Tiebout's seminal article, The Pure Theory of Public Expenditures, did not have much impact on economic scholarship until Wallace Oates demonstrated that Tiebout's theoretical mechanism of citizen mobility had the practical effect of causing the price of land to reflect the quality and tax price of local public goods. Charles Tiebout, A Pure Theory of Public Expenditures, 64 J. POL. ECON. 416 (1956); Wallace E. Oates, The Effects of Property Taxes and Local Public Spending on Property Values: An Empirical Study of Tax Capitalization and the Tiebout Hypothesis, 77 J. POL. ECON. 957, 968 (1969). It took another decade for Tiebout's ideas to penetrate legal scholarship. For a brief history of Tiebout's influence in legal scholarship, see Roderick M. Hills, Jr., Compared to What? Tiebout and the Comparative Merits of Congress and the States in Constitutional Federalism, in The TIEbout Model AT FifTY: Essays IN Public ECONOMICS IN HONOR OF WALLACE OATES 239-53 (William A. Fischel ed., Lincoln Inst. of Land Pol'y 2006). For a survey of Tiebout's influence on economists, see Wallace Oates, The Many Faces of the Tiebout Model, in THE TIEBOUT MODEL AT FIFTY, supra, at 24-42.

42. Tiebout, supra note 41 , at 418-20.

43. Id. at $419-20$ 
constraints in both liberal democracies and authoritarian regimes like the CCP's China prevent such officials from simply being transformed into real estate developers with rights to appropriate such gains in real estate values for personal use. ${ }^{44}$ Absent such personal incentives, however, why should one assume that local officials will care about attracting foot-voters? Foot-voters would be effectively "voting" for officials who did not care about winning the "election." For such migrants, exiting one badly governed jurisdiction in favor of another would be a trip from the frying pan into the fire: Indifferent to whether their communities grew or shrunk, officials would have no reason to be honest or competent as a way to attract migrants.

The fallacy of arguing that citizen mobility can be a substitute for defective voice is illustrated by Professor Ilya Somin's argument that citizen mobility can be a cure for voter ignorance. ${ }^{45}$ Professor Somin reasons that, because citizens who vote with their feet reap all of the gains from their migration, they avoid the well-known incentives for rational ignorance about politics that afflict ballot-voting. ${ }^{46}$ The difficulty with Professor Somin's theory is that, in denigrating citizens' capacity for intelligent exercise of the franchise, he has also undercut the incentives for local officials to care about attracting migrants. Even if there is high demand among such migrants for honest and competent governance, why would any politician care about meeting this demand? By Professor Somin's own hypothesis, voters are rationally ignorant about those politicians' success in boosting local property values. ${ }^{47}$ If the local governments do not care about the migrants, then why should the migrants invest

44. In general, the idea that a public official is a fiduciary of the public bars officials from profiting personally from the performance of their official duties. See generally ANDREW STARK, CONFLICT OF INTEREST IN AMERICAN PUBLIC LIFE 88-95 (2003) (discussing a fiduciary understanding of public office). Accordingly, in both the United States and China, public officials' personal financial gain from an official decision affecting the value of their personal wealth is ordinarily regarded as a conflict of interest requiring the disclosure of the conflict, the recusal of the official, or the reversal of the decision. See generally PATRICIA E. SALKIN, 4 AM. L. ZONING 38.10 (5th ed. 2016); Ting Gong \& Jianming Ren, Hard Rules and Soft Constraints: Regulating Conflict of Interest in China, $22 \mathrm{~J}$. CONTEMP. CHINA 1, 12-14 (2013) (discussing the types of disclosures of conflicts of interest officials are required to make).

45. Ilya SOMIN, Democracy and POlitical IGNorance: Why SMaller GOVERNMENT IS SMARTER 119-20 (2d ed. 2013).

46. Id. at $120-25$.

47. Id. at 141. 
much effort in comparison shopping among the local governments? Professor Somin assumes that local governments compete with each other for migrants, because "[s]tates and localities seek to attract new residents and businesses as sources of tax revenue," but his argument that voters are irredeemably ignorant about politics undercuts this assertion about subnational politicians' incentives. ${ }^{48}$ If voters do not pay attention to politics, then why should canny politicians care about gaining tax revenue? As Albert Hirschman noted, local officials governing a passive population might actually want to deter immigration of more demanding citizens into their city. ${ }^{49}$ If ease of exit rids an organization of pesky "squeaky wheels" while leaving the more quiescent members in place, then the organization managers will encourage exit and provide low-quality services to the passive citizenry who are left behind. ${ }^{50}$ The electoral incentive, therefore, might actually create incentives for local officials to reduce the attractiveness of their communities and thereby drive away potential political opponents, such as members of a different ethnic group. ${ }^{51}$

Professor Somin's theory of local governments' competing for a mobile populace, in short, depends on a theory of informed local voters that the rest of his book rejects. In this respect, Professor Somin's theory of exit is similar to more formal economic models that simply assumed away the problem of a feedback mechanism through which local officials would have incentives to attract the optimal number of migrants. Charles Tiebout's landmark article, A Pure Theory of Local Public Expenditures, ${ }^{52}$ for instance, explicitly rested on the assumption that the local managers sought to maximize the value of local real estate by maintaining the community at its optimal

48. Id. at 145 .

49. See Albert O. HiRschman, EXIT, VOICE, AND LOYALTY: RESPONSES TO DECLINE IN FIRMS, ORGANIZATIONS, AND STATES 124 (1970) ("[M]anagement will," Hirschman argued, "therefore strain to strip the members-customers of the weapons which they can wield, be they exit or voice, and to convert, as it were, what should be a feedback into a safety valve.").

50. Consider, as an example of such an argument, the common complaint that "school choice" undermines public schools' quality by making it easy for the most vocal parents to leave, depriving the parents who stay behind of political clout and sophistication. See generally James S. Liebman, Voice, Not Choice, 101 YALE L.J. 259 (1991).

51. Edward L. Glaeser \& Andrei Schleifer, The Curley Effect: The Economics of Shaping the Electorate, 21 J. L. ECON. \& ORG. 1 (2005).

52. Tiebout, supra note 41. 
size "to lower average costs" of providing local goods.$^{53}$ Economists building on Tiebout's model maintained this assumption without defending it, essentially assuming that mayors were ipso facto entrepreneurial real estate developers seeking to get the highest return on land sales. ${ }^{54}$ But local officials are emphatically not real estate developers. Unless they are corrupt, they derive no automatic benefit from appreciating land prices, and, as noted above, they might very well be disadvantaged by the arrival of nosy, vocal homebuyers into their jurisdiction. Why, then, should local officials try to make their jurisdictions appealing to these foot-voting migrants?

B. Feedback and Foot-Voting: Electoral Voice and Bureaucratic Promotion as Necessary Complements to Exit-Based Control of Local Officials

Theories of exit, in short, require some mechanism aside from the threat of exit itself to motivate local officials. As we explain below, in liberal democracies, that mechanism is the ballot: Local officials care about maximizing local property values because local voters punish these officials when home prices go down. In authoritarian regimes, the necessary mechanism is bureaucratic promotion by CCP superiors. What reason is there to believe that either voters or CCP superiors are either willing or able to enforce their criteria for promotion and demotion against local officials?

\section{The Homevoter Hypothesis as Feedback Mechanism Linking Ballot-Voters and Foot-Voters}

Consider, as an example of such an amalgamation of exit and voice in liberal democracy, William Fischel's influential "homevoters hypothesis," in which local voters' inability to exit forces them to participate effectively and intelligently in politics. ${ }^{55}$ "Homevoters," in Fischel's lexicon, are simply local residents who are held hostage to their local government's decisions affecting local real estate's value

53. Id. at 419 ("The last assumption is that communities below the optimum size seek to attract new residents to lower average costs. Those above optimum size do just the opposite. Those at an optimum try to keep their populations constant.").

54. See, e.g., Jon C. Sonstelie \& Paul R. Portney, Profit Maximizing Communities and the Theory of Local Public Expenditure, 5 J. URB. ECON. 263 (1978) (arguing that "if communities act as if they are profit maximizing firms, resources will be efficiently allocated to the provision of local public goods.").

55. FISCHEL, HOMEVOTER HYPOTHESIS, supra note 40. 
because they purchased that real estate before the decisions were made. ${ }^{56}$ Because potential homebuyers will take into account the predicted effect of those decisions when making their bid, homevoters cannot escape the value-lowering decisions of incumbent politicians by selling their land ${ }^{57}$ Homevoters must stand and fight-and they fight hard, overcoming the ignorance about politics that normally affects their ballots, because a huge and uninsurable portion of their assets are tied up in their land investment, making such ignorance less rational. ${ }^{58}$ Because homebuyers pay more for low taxes, value-enhancing zoning regulations, and high-quality (mostly educational) services, the value of the political decisions creating such conditions will be "capitalized" into the value of the homes that homevoters have purchased, giving every homevoter an incentive to show up at planning commission hearings and city council meetings even if they do not have kids in school. ${ }^{59}$ Under Fischel's model, in other words, local politics ("voice") depends on a combination of homebuyers' freedom of movement ("exit") and homevoters' lack of exit. The former gives local voters information about how local decisions affect net welfare. The latter gives local voters incentive to pay attention to this information.

2. Cadre Promotion Criteria as the Feedback Mechanism Linking the CCP and Foot-Voters: The Case of "Market-Preserving Federalism"

What analogous mechanism provides feedback in authoritarian systems, where local officials are not responsible to local homevoters through elections? One mechanism is bureaucratic promotion criteria. To the extent that an official's chance of promotion is enhanced by the official's attracting migrants to his or her jurisdiction, that official will have incentives to cater to foot voters just as much as if the migrants actually enjoyed the ballot, because the foot-voting migrants would hold the fate of the official in their collective hands. In effect, the central CCP authorities would play the role of homevoters in Fischel's system, judging the performance of local cadres by their proficiency in attracting homebuyers.

Would local cadres really cater to foot-voting households if the criteria for promotion in China's cadre evaluation system (ganbu

$\begin{array}{ll}\text { 56. } & I d . \text { at } 4-6 . \\ 57 . & I d . \text { at } 59-61 . \\ 58 . & \text { See } \text { id. } \text { at } 39-72 . \\ 59 . & \text { Id. at } 8-10,29-31 .\end{array}$


kaohe zhidu，干部考核制度） were more closely tailored to cadres' proficiency in attracting homebuyers? Just as local voters might be indifferent to local elections, CCP superiors in Beijing might also be indifferent to official promotion criteria, relying instead on personal ties and factional loyalties between local officials and CCP leaders. ${ }^{60}$ On the other hand, it is also possible that central authorities might care about official promotion criteria at the middle levels of subnational government-such as prefecture-level cities, urban districts, and counties-because there the familial connections to the highest CCP elites in Beijing are rare, but the positions are also too removed from the highly localistic kinship networks that control subcounty politics. ${ }^{61}$

Both anecdotal and more systematic evidence suggests that, at least for those mid-level subnational posts, the official promotion criteria matter: When those criteria require local cadres to compete with each other to appeal to private actors such as private investors or tourists, cadres aggressively conform to those criteria. ${ }^{62}$ Consider, for instance, the idea that the Chinese system of subnational government is "market-preserving" in that it is responsive to the demands of mobile capital. Most famously defended by Montinola, Qian, and Weingast in the mid-1990s, ${ }^{63}$ the "market-preserving" theory of federalism is rooted in the hypothesis that subnational officials will abstain from predatory expropriation of investment capital if they are evaluated on the basis of their jurisdiction's GDP and revenue. ${ }^{64}$ Official promotion criteria have historically emphasized a local government's GDP and revenue generation, ${ }^{65}$ and

60. See Victor Shih et al., supra note 33, at 167.

61. For a study of subcounty official positions dominated by local elites, see Feng Junqi (冯军旗), Zhongxian Ganbu (中县干部) [Party Cadres in Central County] (June 2010) (unpublished PhD dissertation, Peking University).

62. For a humorous example of such competition, consider the reality TV show "Sights of Shanxi" in which Chinese mayors are evaluated before a studio audience by their superiors on their capacity to attract tourists to their cities. The mayors vie with each other to sell their cities, making often colorful pitches and earning tough public criticism from a panel of judges when their pitches are rejected. See You're stir-fried squid, ECONOMIST (June 18, 2016), http://www.economist.com/news/china/21700687-youre-fired-chinese-officials-meet -apprentice-youre-stir-fried-squid.

63. See Gabriella Montinola et al., Federalism, Chinese Style: The Political Basis for Economic Success in China, 48 WORLD POL. 50 (1995).

64. Id. at 70

65. See PierRe F. LANDRY, DECENTRALIZED AUTHORITARIANISM IN CHINA: 'The Communist Party's Control of Local Elites in the Post-Mao ERA 
the link between both of these criteria and private investment in land is plain enough. Moreover, the evidence suggests that Chinese local officials seeking promotion aggressively protect the interests of the owners of mobile capital just as they are instructed to do by the official criteria favoring economic growth. ${ }^{66}$

GDP and revenue, as noted above, are only imperfectly related to the welfare of Chinese households. The responsiveness of local cadres to foot-voting by owners of investment capital, however, suggests that, just as competition for promotion induces cadres to cater to the needs of investment capital, so too cadres might be induced to promote Chinese households' interests if households' foot-voting was made a central criterion for bureaucratic promotion. As we explain below in Part III, one way to align cadres' incentives with the foot-voting choices of households is to base bureaucratic promotion on the value of land within a local cadre's jurisdiction.

\section{USING LAND VALUES AS THE BeST PROXY FOR HOUSEHOLDS' FOOT-VOTING}

How can bureaucratic promotion criteria best be aligned with the choices of China's foot-voting households? We suggest that the link is best expressed by a simple, single number: The change in a local government's aggregate land prices over the period for which a local cadre is being evaluated. Land prices that rise suggest that the local government is attracting mobile households, while falling land prices suggest that foot-voting households are choosing other jurisdictions. In liberal democracies, "home voters"-meaning residents who elect local officials-use this price signal as a guide for re-electing or throwing out incumbent officials. In authoritarian regimes, the ruling regime's bureaucratic evaluators of local officials can likewise use land values as a yardstick by which to measure official performance. In response, local officials will plausibly respond by trying to boost land values, just as they tried to boost the number

(2008) (observing that economic growth has been the major evaluation criterion in the handbook of the CCP Central Personnel Department (中组部)).

66. For a survey of evidence that local officials compete for investment to obtain promotions, see Chenggang Xu, The Fundamental Institutions of China's Reform and Development, 49 J. ECON. LIT. 1076, 1079 (2011), http://www.sef.hku.hk/ cgxu/04_Xu.pdf. For evidence that success in winning revenue actually earns promotions for county-level officials, see Hongbin Li \& Li-An Zhou, Political Turnover and Economic Performance: The Incentive Role of Personnel Control in China, 89 J. PUB. ECON. 1743 (2005). 
of GDP, which has been the main criteria of cadre evaluation and promotion in the past two decades. We argue that this incentive will generally induce such officials to make their jurisdictions attractive to home buyers-in effect, campaigning for re-election before a constituency of foot-voters.

\section{A. The Basic Defense of Land Values as the Best Proxy for Foot-Voters' Choices}

Why should land prices, rather than a jurisdiction's net population gain or loss, constitute the best measure of a local government's ability to attract foot-voters? The reason is that land prices provide more information about citizens' preferences. As early as 1979, Arnott and Stiglitz noted that "the practice of inferring individual valuations of public goods from land values is now widespread." ${ }^{67}$ As Anup Malani has noted, the amount by which a bid on a house in one jurisdiction exceeds bids on identical houses in other jurisdictions is a measure of how much more the bidder values the more expensive jurisdiction. ${ }^{68}$ Such relative desirability is influenced by local officials' decisions about education, traffic regulation, crime control, and overall governmental efficiency, which are reflected-in economic jargon, "capitalized"-in real estate prices ${ }^{69}$ If land prices in one jurisdiction are much higher than land in neighboring and otherwise identical jurisdictions, then this difference is an indication that the former jurisdiction's land is much better governed than the latter jurisdiction's. ${ }^{70}$ If one is interested in the intensity as well as the direction of citizens' preferences, then higher land prices are superior to demographic growth as an

67. See Richard J. Arnott \& Joseph E. Stiglitz, Aggregate Land Rents, Expenditure on Public Goods, and Optimal City Size, 93 Q. J. ECoN. 471, 471 (1979).

68. This point is ably defended by Anup Malani. See Anup Malani, Valuing Laws as Local Amenities, 121 HARV. L. REV. 1273, 1273 (2008). In general, our argument in this section is consistent with and relies upon Malani's argument.

69. FISCHEL, HOMEVOTER HYPOTHESIS, supra note 40, at 39-72 (explaining capitalization).

70. Id:; see also, Vicki Been, "Exit" as a Constraint on Land Use Exactions: Rethinking the Unconstitutional Conditions Doctrine, 91 CoLUM. L. REV. 473, 514-529 (1991) (discussing capitalization; studies indicate that consumers consider a community's public service and tax packages when deciding which jurisdiction to live in). 
indication of what and how much foot-voters value the amenities offered by a local government. ${ }^{71}$

Land prices shaped by citizens' foot-voting help solve the dilemma of democratic centralism outlined in Part I above-the dilemma of administratively simple yet substantively complete promotion criteria. The CCP wants to take into account all aspects of cadre performance that affect citizen welfare, but the CCP also needs to have criteria that yield some definite result when rival local officials compete for a promotion. How, then, to rank cadres who score differently on different criteria? How does one decide to award a promotion in a contest between the most frugal mayor, the mayor with the environmentally cleanest city, the mayor with the highest employment, and the mayor with the best educated children? Each out-performed the others in some respect but not in others: The CCP needs a simple bottom-line factor that will aggregate each of these values in a way reflective of citizen preferences. Because homebuyers take into account every aspect of a jurisdiction's quality when making a bid, land prices should "capitalize" otherwise incommensurable aspects of governmental performance into a single number ${ }^{72}$ Unlike numerical weights that the CCP assigns to different aspects of cadre performance, land prices are not arbitrary decisions by the CCP, but instead reflect the collective ranking of these aspects by millions of foot-voting citizens. Land prices, therefore, put the "democratic" back into "democratic centralism," allowing the CCP to infer what citizens really value from what they are willing to pay. ${ }^{73}$

Instead of land prices informed by citizens' foot-voting, one might attempt to rely on survey instruments to rank cadres on their effectiveness in satisfying their constituents, as suggested by $\mathrm{Li}$ and Liang. ${ }^{74}$ But such direct measurement of satisfaction imposes enormous information costs on cadres' supervisors. As Li and Liang acknowledge, "[c]ompared with economic growth, inhabitants'

71. The defense of land prices over simple demographic change is analogous to the defense of the single transferable vote over first-past-the-post plurality elections.

72. FISCHEL, HOMEVOTER HYPOTHESIS, supra note 40, at 5-6 (noting that homeowners think holistically about local government).

73. See Malani, supra note 68, at 1309-11.

74. See Shujuan Li \& Yan Liang, Competition Model and the Change of Local Governments' Behavior and Governance of China's Local Government Debt, 49 CHINESE ECON. 199 (2016) (providing such an argument for tournaments between local officials who are assessed by the relative satisfaction of the citizens that they govern). 
satisfaction is more difficult to measure." ${ }^{75}$ They suggest that inhabitants of local government score their officials on various indices related to health, education, the environment, etc. There is little reason to believe, however, that mere public opinion surveys are an effective way to discern what citizens really want. As Professor Ilya Somin notes, even with all of the safeguards of liberal democracy-an independent press, competitive political parties, and organized interest groups-voters are afflicted by political ignorance and collective action problems that depress turnout and lead to uninformed voting. ${ }^{76}$ Mere public opinion polls would suffer from proportionately greater problems of rational voter ignorance and collective apathy, because essential devices for organizing and informing voters (for instance, independent newspapers and interest groups) do not exist in China. ${ }^{77}$

Land prices informed by citizens' foot-voting, by contrast, provide an indication of citizens' preferences that is not only simple and relatively accurate but also ideologically safe. Homebuyers make individualized rather than collective judgments about the value of real estate: Households do not ordinarily hold a public meeting in order to put a bid on a house. The individualistic character of their home-purchasing decisions alleviates collective action problems faced by voters (or citizens being polled) in acquiring information, because each homebuyer faces large stakes and reaps all of the gains from their research into the competing merits of local governments. ${ }^{78} \mathrm{At}$ the same time, such individualistic household choices to purchase a particular asset do not announce to the world any abstract normative principles that compete with the CCP's own ideology. The private and self-interested character of their foot-voting, therefore, minimizes the chance that their judgments could constitute the spark that sets off a prairie fire of revolution against the CCP. Homebuyers on the move do not congregate in crowds, wave placards, shout angry slogans, or burn police cars. From the point of view of civic participation, these traits are strikes against foot-voting. From the point of view of the CCP, however, the private and individualistic character of house shopping is not a bug but a feature: Bids on real estate provide much of the same information that actual elections would provide without the risk that a narrow vote on garbage collection or quality of schools

\footnotetext{
75. Id. at 207.

76. See SOMIN, supra note 45 , at 117-18.

77. See supra Part I.

78. SOMIN, supra note 45 , at 121-25.
} 
will suddenly and unexpectedly become a referendum on the legitimacy of CCP rule.

\section{B. Refinements and Qualifications}

The basic idea that land prices should play a central role in the evaluation of cadres is simple enough-in fact, too simple. Below, we offer some refinements and qualifications.

\section{Henry George to the Rescue: Measuring land prices rather than real estate prices}

First, why focus on land prices rather than the price of real estate generally? The focus on land adds an administrative headache to the evaluation process, because it requires the evaluators to determine the share of real estate's value contributed by lots as opposed to structures. Nevertheless, land prices have an advantage over housing prices as an index of cadre performance because, unlike housing, the supply of land is ordinarily fixed by nature and cannot be reduced by local government policies. ${ }^{79}$ By contrast, cadres who wanted to drive up the price of housing could do so by using zoning regulations to restrict the production of housing or by holding state-owned land off the housing market. If demand for housing in those cadres' jurisdiction was price-inelastic, then the price of housing would be boosted, but foot-voters would be left unsatisfied, prohibited from migrating to a jurisdiction by an artificial housing shortage. By focusing on the value of land, one avoids this perverse incentive for officials to restrict the construction of new housing, as such restrictions would cause the value of restricted lots to fall, not increase. ${ }^{80}$ One can analogize this argument for basing bureaucratic promotion on land values to Henry George's argument for basing taxation on the value of vacant land rather than the value of structures built on that land. Henry George, the $19^{\text {th }}$ century journalist and economic reformer, argued that, by taxing away $100 \%$ of the value of a vacant lot, government would not diminish the incentives of the lot's owner to build, because landowner could not

79. Local governments abutting the coast can sometimes increase the supply of land by filling in coastal areas.

80. See Malani, supra note 68, at 1293-94 (explaining that the appropriate measure of a law's value if that law affects housing supply is a land-based rather than housing-based pricing metric). 
avoid the tax by removing the land from the taxing jurisdiction. ${ }^{81}$ This same inelasticity of land's supply likewise prevents local officials from affecting land prices with supply-reducing policies.

2. Comparing Apples to Apples: Measuring change in local governments' land prices relative to land price change in the metropolitan area

Not all regions are equal. Weather, natural features like harbors and rivers, geographic proximity to population centers, economic activity, and many other features give some regions an inherent advantage over their rivals that no amount of expertise in government can eliminate. The mayor of Ma'anshan in the inland province of Anhui cannot move his city closer to the Pearl River Delta, no matter how well he allocates and manages his city's money and rules. Competition for foot-voters between Ma'anshan and the City of Guangzhou, therefore, is a rigged race: Such a competition would give no incentive to the inevitable losers to improve their performance. To the contrary, as Cai and Treisman note, competition for mobile investors between jurisdictions with such different inherent endowments could lead to a "polarization effect" in which foot-voters all favor the better endowed while "[p]oorly endowed units, knowing they will lose, simply give up." ${ }^{2}$

To ensure fair comparisons, therefore, cadres ought to be compared not on the basis of the absolute aggregated value of land in their jurisdiction but rather on the basis of the change in that land's value during the relevant period of evaluation. If the mayor of Ma'anshan managed to increase land values in his jurisdiction by a higher percentage than the percentage increase achieved by the mayor of Guangzhou, it would be odd to say that the latter outperformed the former merely because Guangzhou land prices were higher than Ma'anshan land prices.

81. HENRY GEORGE, PROGRESS AND POVERTY: AN INQUIRY INTO THE CAUSES OF INDUSTRIAL DEPRESSION AND INCREASE OF WANT WITH INCREASE OF WEALTH 433-38 (Robert Schalkenback Found. ed., 1935) (1879). The Liberty Fund's Concise Encyclopedia of Economics provides a description of Henry George's ideas and influence. Charles L. Hooper, Henry George (1839-1897), in LIBRARY OF ECONOMICS AND LIBERTY: THE CONCISE ENCYCLOPEDIA OF ECONOMICS, http://www.econlib.org/library/Enc/bios/George.html.

82. Hongbin Cai \& Daniel Treisman, Does Competition for Capital Discipline Governments? Decentralization, Globalization, and Public Policy, 95 AM. ECON. REV. 817, 828 (2005). 
Likewise, cadres' success or failure in raising land values should be assessed by comparing land in their jurisdiction only against land within the same metropolitan area. Factors beyond any local government's control—say, global warming and rising sea levels or central government spending in a particular area-might affect the value of land. Mayors who outperform their metropolitan areas should not be punished simply because their region happens to fall behind rival regions because of these extra-local factors. By narrowing the range of competing local governments and focusing on change in value regardless of starting or ending values, the central evaluators of local officials can narrow (although not entirely eliminate) endowment advantages. ${ }^{83}$

\section{Avoiding Short-term Bubbles with Medium-term Land Values and Fiscal Contraints}

In using land prices to evaluate cadres, it is important to avoid creating incentives for cadres to inflate short term land bubbles in order to win promotions. There are, of course, ways in which local officials can temporarily increase the price of land without improving governance. Simply by subsidizing land purchases with low-interest loans, a local government could pump up a real estate bubble that would deflate as soon as the subsidies ran out. More generally, the CCP's practice of rotating local officials through several subnational jurisdictions for very short (less than five-year) tenures in each jurisdiction can also reduce local officials' incentives to attend to the long-term consequences of their decisions. ${ }^{84}$

83. The evaluation criteria for an official governing Local District (LD) located in a Metropolitan Area (MA) can be expressed in the following formula. For each $L D_{n}$, calculate ration as $\Delta$ total land value in $L_{n} / \Delta$ total land value in

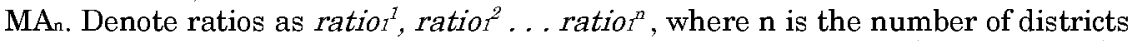
within the metro area. Standardize these ratios as: ratiot $_{-} S=$ [ratior $^{i}-$ mean $($ ration $)] /$ std $\left._{(\text {ratio }}\right)$, for $\mathrm{i}=1,2 \ldots \mathrm{n}$ where $\operatorname{mean}($ ratio $)=\left(\right.$ ratio $^{1}+$ ratior $^{2}$ $+\ldots+$ ration $\left.^{n}\right) / n$. Std(ration) is the standard deviation of ratio1.

84. As indirect evidence of the costs of rapid turnover of officials, consider evidence that enterprises postpone investment and banks were more reluctant to loan money to local governments during the turnover period. Yang Haisheng et al. (杨海生), Zhengce Bulianxuxing yu Caizheng Xiaolü Sunshi-Laizi Difang Guanyuan Biangeng de Jingyan Zhengju, (政策不连续性与财政效率损失一来自地方 官员变更的经验证据) [Discontinuition in Policies and Loss of Financial EfficiencyEmpirical Evidence from the Change of Local Officials], GUANLI SHIJIE (管理世界) [MGMT. WORLD], Dec. 15, 2015, http://www.mwm.net.cn/_d277131452.htm; Luo Danglun \& She Guoman (罗党论 \& 佘国满), Difang Guanyuan Biangeng yu Difang Zhai Faxing (地方官是变更与地方债发行) [Change of Local Officials and Issuance 
One way to lengthen local officials' time horizon is to tie cadres' fate to the medium- and long-term value of land in the jurisdictions that they govern. One possibility is to tie their promotion to the rolling average of changes in the price of land over several years. Such evaluations could give cadres incentives to care about the long-term consequences of their policies by tying cadres' evaluations not only to changes in the price of land in jurisdictions that they currently manage but also the price of land in jurisdictions where they were formerly assigned. The longer the period of time over which the average land price change is calculated, the more the cadre would have incentives to adopt policies that would create lasting values rather than short-term bubbles.

Suppose, for instance, that cadres were evaluated on the basis of a five-year rolling average of land prices, using land in not only current, but also former jurisdictions to calculate such averages. Under such an evaluation procedure, a cadre who had served for three years as a county party secretary after formerly serving as a township party secretary for the previous three years would be evaluated not only on the basis of the three-year performance of land in his county where he was an incumbent but, also on the basis of the performance of land prices for the previous two years in his former township-two years after he left township office. Faced with the prospect of being evaluated by changes in land prices in jurisdictions following the end of their tenure there, outgoing local officials would have incentives to install supporters in key positions so their value-enhancing reforms could continue past the end of their term. ${ }^{85}$

To further avoid short-term bubbles, the central government should incorporate local debt burdens into local government leaders' evaluations. A local leader can manipulate public investments to maximize land value during his term, but such manipulation can compromise a city's long-term growth potential. Considering the

of Local Debt], JINGJI YANJIU (经济研究) [ECON. RES. J.], Oct. 13, 2015, $\mathrm{http} / / / \mathrm{www}$.cesgw.cn/cn/NewsInfo.aspx?m=20100914093049340648\&n=201510131 42944963970 . Homebuyers seem to share the same concern about short-tenured mayors as investors and banks. Thousands of citizens of Datong City, Shanxi Province, stopped Yanbo Geng, the Chinese mayor featured in a BBC documentary, on his way out of the city for a better position because they were concerned that Geng's urban redevelopment projects and policies would not be continued by his successor. THE CHINESE MAYOR (Zhaoqi Films 2015).

85. Leaders at the county/urban district level or below have the power to recommend and evaluate their potential successors according to Article 25 of the 2009 Work Regulations on Promotion of Party and Government Leaders. 
importance of local government finance and the time bomb of huge local government debt in China, additional safeguards are in order where local governments' debt is concerned. In theory, bondbuyers and homeowners might together punish local officials who incur excessive debt by bidding lower amounts for land and bonds. In practice, however, the likelihood that the central government will bail out local governments before they go bankrupt encourages local officials to incur, and lenders to finance, excessive debt based on the national government's credit. ${ }^{86}$

\section{Protecting Workers: Qualifying land values with rent-income ratio ("RIR")}

The CCP has goals aside from encouraging value-maximizing governance. They are, after all, communists with presumptively egalitarian priorities. They are also practically wary of the negative effect of unaffordable housing on economic and social development. Such awareness and concern are an important motivation for the central government issuing orders to local governments to cool down the housing market in the past two decades. As written in a State Council ordinance, "housing matters to national economy and people's livelihood; it is an economic issue, but more importantly an issue of people's livelihood that impacts social stability." ${ }^{87}$ Local governments are also concerned that unaffordable housing might crowd out talent. As Yu Zhensheng, former party secretary of Shanghai and now Chairman of the National Political Consultative Conference Standing Committee said, "Shanghai would lose its advantage in human

86. See generally JONATHAN A. RODDEN, HAMILTON's PARADOX: THE PROMISE AND PERIL OF FISCAL FEDERALISM (2005) (discussing the tendency of subnational governments to impose exernal costs on the budgetary commons by borrowing on the de facto credit of the national government). For the challenges of imposing a hard budget constraint ex ante on local officials in China, see Jing Jin \& Heng-fu Zou Soft Budget Constraints and Local Government in China, in Fiscal Decentralization and THE Challenge of HaRd Budget Constraints 289 (Jonathan A. Rodden et al. eds., 2003). As Arnott and Stiglitz argued, the idea that local public goods are capitalized into land rents does not insure that cities will compete for optimal number of residents, because the Arnott-Stiglitz model's equilibrium is partial insofar as it does not incorporate any local government budget balance constraint. See Arnott \& Stiglitz, supra note 67, at 491.

87. Guowuyuan Bangongting (国务院办公厅), Guowuyuan guanyu Jianjue Ezhi Bufen Chengshi Fangjia Guokuai Shangzhang de Tongzhi (国务院垁于坚决遏 制部分城市房价过快上涨的通知) (Apr. 17, 2010), http://www.gov.cn/zwgk/201004/17/content_1584927.htm. 
resources if it cannot resolve the housing problem." ${ }^{88}$ Han Zheng, former mayor and now party secretary of Shanghai, also said that "Shanghai has no future if it cannot resolve the problems of 'snail house' and 'home mortgage slave' for new Shanghaiers." ${ }^{89}$

Thus to ensure that local officials minimize the disruption and unfairness of rents outstripping wages, the central evaluators ought to consider the ratio of rent to income in making promotion decisions. Local officials who preside over rising ratios in which residents pay an ever-higher percentage of their income for rent should not be rewarded regardless of how much their jurisdiction's land prices appreciate relative to those in their metropolitan area. Indeed, the CCP already takes into account the "property-income ratio" in making promotions. ${ }^{90}$ This qualification on the use of land values, therefore, simply preserves a bit of the status quo.

One might protest that there is an inherent contradiction in rewarding mayors for increasing land prices but punishing them for escalating rents and falling wages. After all, an influx of homebuyers to a jurisdiction will, ceteris paribus, predictably cause rents to rise and wages to fall. ${ }^{91}$ Why does a steady rent-income ratio criterion not simply cancel out appreciating land values? The reason is that matters are not ceteris paribus. The enterprising local official should fight rising rents with more housing. As more foot-voters pour into a popular jurisdiction, local officials can increase the supply of housing by increasing the density and quantity of residentially zoned land. If supply of housing matches the demand, then rents should stay steady even as prices of a unit of land appreciate, because more people will live on the same amount of land. Local officials can, in short, simultaneously attract new homebuyers and expand the housing supply to make room for them. ${ }^{92}$

88. Liu Xuezhong (刘学忠), Fangjia Paomo xia Jingji Fazhan Pingjing Xianxian (房价泡沫下经济发展瓶颈显现), ZHONGXIN WANG (中新网) (Jan. 21, 2011), http://www.chinanews.com/estate/2011/01-21/2802863.shtml.

89. Id.

90. See Chen Qinggui (陈庆贵), Kaoji “Fangjia Shouru Bï" Xu Bawo Sange Guanjian (考绩“房价收入比”须把握三个䏌键) [Three Keys for Incorporating Price-Income Ratio in Evaluation], CHINA News, Jan. 24, 2011, http://www.china news.com/estate/2011/01-24/2806953.shtml; Jinri Jujiao: Fangjia Shouru Bi Naru Guanyuan Kaohe Kaopu ma?(今日聚焦：房价收入比纳入官员考核靠谱朋?) [Today's Focus: IS It Plausible to Incorporate Price-Income Ratio in Cadre Evaluation?], SINA, Aug. 1, 2016, http://dichan.sina.com.cn/sh/zt/136guanyuan/.

91. See Malani, supra note 68, at 1280-90.

92. Chongqing looks to be a city with a rapidly growing economy and stable housing prices. According to newpaper reports, the Chongqing government has 
There are admittedly limits on the degree to which the technology of housing density can match rising demand. Higher densities can erode demand for land because density sometimes has costs - especially where the supply of land is tight, such as crowded sidewalks, shadows from tall buildings, and the like. These features of density make land less attractive and force local officials to choose between raising housing supply but reducing demand (i.e., making their jurisdictions marginally less attractive to foot-voters) or protecting land values but displacing wage-earners who cannot keep up with the rising rents.

This dilemma, however, might be more theoretical than real. Chinese local governments tend to control large territories with plentiful non-residential land. ${ }^{93}$ There would not likely be many circumstances in which the only way extra foot-voters could be housed would be to build skyscrapers next to scenic views or demolish historic districts. Even when such a conflict between increased supply of and demand for housing arose, however, the dilemma could be solved simply by evaluating officials on a weighted average for each value. Under such a dual-factor system, each local government would be rated not only on the basis of the change in land prices within their local government relative to land prices in their metropolitan area but also on their local government's change in the rent-income ratio relative to changes in the metropolitan rent-income ratio. Officials who scored well on attracting foot-voters but poorly on increasing housing supply would lose out in such a tournament to officials who took a more balanced approach to development. ${ }^{94}$

managed to control housing prices by increasing land supply and building social housing. See Christian Shepherd, How One City in China is Trying to Avoid a Property Boom and Bust, FIN. TIMEs (Oct. 25, 2016), https://www.ft.com/ content/2d117204-9758-11e6-a1dc-bdf38d484582.

93. See Kam Wing Chan, Urbanization and Urban Infrastructure Services in the PRC, Financing Local Government in the People's Republic of CHINA, 83-125 (Christine P.W. Wong ed., 1997) (discussing the large amounts of rural land within prefectural-level and county-level cities).

94. Again, the criteria can be expressed by a formula similar to the ratio set forth supra at note 83. This second ration compares the RIR in Local District $\left(\mathrm{LD}_{\mathrm{n}}\right)$ to the RIR in that LD's metropolitan area (MA). Calculate a standardized ratioz, $\triangle \mathrm{RIR}$ in $\mathrm{LD} / \Delta \mathrm{RIR}$ in MA, and denote them as ratio ${ }^{1}{ }_{-} \mathrm{s}$, ratio2 ${ }^{2}{ }_{-} \mathrm{s}$...ration ${ }^{\mathrm{n}}{ }_{-} \mathrm{s}$. The weighted average this standardized ratio with the ratio of $\mathrm{LD}$ to MA land prices set forth in supra note 63 is $\mathrm{a}^{*}$ ratio ${ }^{\mathrm{i}}{ }_{\mathrm{S}} \mathrm{s}+\mathrm{b}^{*}$ ratio ${ }^{\mathrm{i}} \mathrm{s}$, where $\mathrm{a}+\mathrm{b}=1$. 


\section{FoOT-Voting With CHINESE CHARACTERISTICS: THREE FEASIBLE InSTITUTIONAL REFORMS TO IMPROVE CITIZEN MOBILITY}

The defense of foot-voting and land values offered above ignores the specifics of local governments' design. However, those details matter. The size, number, and powers of local governments dramatically affect the capacity of citizens to vote with their feet. For foot-voting citizens to make meaningful choices among competing jurisdictions, there must be a sufficient number of jurisdictions among which to choose. The citizens' choices should also not be muddied by radical differences among the competing jurisdictions' private goods like higher wages and job opportunities. Moreover, citizens' migration must trigger not only the right to receive local services but also the obligation to pay for them; otherwise, such migration does not reveal that the citizens value governmental services at the cost of supplying them. Local officials must have the power to respond to migrants' demands by extending services to newcomers and charging those newcomers for the services' costs. In this section we address and provide practical remedies for three institutional obstacles to foot-voting: limited fiscal instruments, improper size of local governments, and the hukou system.

\section{A. The Problem of Limited Fiscal Instruments}

A citizen's decision to migrate to a local government's territory reveals that the migrant values the benefits of that local government's services more than those services' costs only if that citizen must pay those costs (primarily taxes) in order to receive those benefits. The decision to migrate to a jurisdiction, therefore, should trigger not only the right to receive services a local government offers but also the obligation to pay for them. Chinese local governments, however, cannot easily maintain such a link between the right to receive and the obligation to pay for public services, because Chinese law severely limits local governments' fiscal instruments. The result of such fiscal inflexibility is not only that local governments frequently gain no additional revenue from new migrants but also that local officials cannot improve land values by supplying services at lower costs than neighboring jurisdictions. Both limits prevent good governmental policies from being reflected in land prices.

The obvious solution is to broaden the range of local governments' taxing powers-and, in particular, to give local governments the power to impose property taxes. Proposals to vest 
local governments with property-taxing powers have been broached before, but such power has not been popular with the CCP because of its potential to trigger urban unrest among aggrieved property owners. We argue below, however, that such a tax is politically feasible if it is tied up with more autonomy over tax revenues and more influence by taxed interests over the expenditure of those revenues to enhance local property values.

\section{How Lack of Taxing Power Impedes Foot-Voting}

Most local taxes in China are skewed towards business-driven revenue, such as value-added taxes, corporate income taxes, and business taxes, while taxes on housing ownership have not been substantial. ${ }^{95}$ Local officials' lack of taxing power results in their interests running counter to citizens' foot-voting: Local officials have an incentive to exclude new migrants whom they cannot tax even if the economy of a jurisdiction would benefit from more people. Despite evidence that the population of Chinese cities is currently too small for labor to realize its highest value ${ }^{96}$ leaders of Chinese cities often complain about new migrants, egged on by angry residents fearful that newcomers will crowd schools and roads. ${ }^{97}$ Such complaints make sense to the extent that local governments are unable to

95. Local governments also derive revenue from property-related taxes including the urban maintenance and construction tax, urban and township land use tax, farmland occupation tax, and land appreciation tax. These taxes are mainly paid by real estate developers and comprise about 10 to 15 percent of local tax revenue while direct land sales revenue ranges between half of to higher than total tax revenue in many Chinese cities. See, e.g., Tudi Caizheng Yujing: Difang Zhengfu Mai Di Quansheng Shiqi Yijing Jieshu (土地财政预警：地方政府卖地全盛 时期已经结束) [Land Finance Alarm: The Best Time for Selling Land Has Passed], SINA (May 23, 2015), http://finance.sina.com.cn/china/20150523/110322250 448.shtml (stating that a land transaction fee has been a main source of government revenue).

96. See Chun-Chung $\mathrm{Au} \& \mathrm{~J}$. Vernon Henderson, Are Chinese Cities Too Small?, 73 REV. ECON. STUD. 549 (2006).

97. See, e.g., Hui Ge (辉格), Chengshi Paiwai Qingxu Buke Zhuzhang (城市 排外情绪不可助长) [Don't Promote Xenophobia in Cities], NANFANG WANG (章方网) (Dec. 18, 2012), http://view.qq.com/a/20121218/000001.htm (refuting xenophobic arguments such as that a migrant population takes away educational and economic resources from locals); Fei Hujisheng Zhengqu Yidi Gaokao Bei Chi Huangchong Gunchu Shanghai (非沪籍生争取异地高考被厉蝗虫滚出上海), NANFANG WANG (南方网) (Dec. 3, 2012), http://edu.sina.com.cn/gaokao/2012-1203/1115364244.shtml (reporting that a student who has no hukou in Shanghai but petitioned to take the college entrance exam there was called a "locust" and was demanded to get out of Shanghai). 
recover the costs of providing services to new migrants because they are legally disempowered from imposing taxes on residential property. ${ }^{98}$

In theory, local governments' ground leases of state-owned land to private lessees, which last up to 70 years depending on the land use, might mitigate or even eliminate these perverse fiscal incentives. As a concession to local governments, the central government gave its share in land sales revenue to local governments in the 1998 revision to the Land Administration Law. ${ }^{99}$ Since then, with the growth of the Chinese real estate market, land sales revenue has become an important source of revenue for local governments, growing from $28.39 \%$ to $71.68 \%$ in local budgets from 2002 to 2010, and making up $34.9 \%$ of the revenues of prefectural-level cities in $2010 . .^{100}$

Such ground leases offer important advantages over local governments' other sources of revenue because they give local officials the flexibility and incentives to tailor revenue, regulations, and expenditures to foot-voting lessees. Because lessees might be expected to pay more for land that is well-governed, ${ }^{101}$ ground leases give local officials a fiscal incentive to maximize the value of land in their regulatory decisions. The long terms of ground leases, however, make them an extraordinarily inelastic device by which to recover the revenue needed to run a local government. The leases give the local government no capacity to recover additional revenue from lessees during the life of the lease based on the local government's success in attracting new migrants and thereby enhancing the value of leased land. A new mayor whose city's land has already been leased out cannot recover revenue from the lessees to improve the city with new post-lease amenities, even if those amenities are precisely what foot-voters are currently seeking. In calculating the lessee's payment at the outset of the lease, therefore, local officials will somehow need to predict their government's financial needs and the likely benefits of

98. See infra note 103.

99. Shitong Qiao, The Politics of Chinese Land: Partial Reform, Vested Interests, and Small Property, 29 CoLUM. J. AsIAN L. 70, 85-86 (2016).

100. See Asian Development Bank, Local Public Finance Management in the People's Republic OF China: Challenges AND OPPORTUNITIES 23 (2014).

101. See Montinola et al., supra note 63, at 58 ("Jurisdictions are thus induced to provide a hospitable environment for factors, typically through the provision of local, public goods . . . Those jurisdictions that fail to provide these goods find that factors move to other jurisdictions."). 
the local government's expenditures over the several decades of the life of a lease-a challenge in prophecy that might intimidate even the most prescient gamblers. The uproar occasioned by the City of Wenzhou's charging lessees substantial sums to renew their land leases demonstrates the risk of disconnecting government's land revenue from private property value. ${ }^{102}$

Local Chinese governments also do not control the rate and base of the fiscal instruments from which they derive their revenue. Because the rate and base even for "local" taxes are defined by national law, subnational governments cannot compete with each other by offering a reduced tax burden to prospective homebuyers. ${ }^{103}$

\section{How to Make a Local Property Tax Politically Feasible}

There is an economically obvious, normatively appealing, but politically challenging solution to local governments' limited fiscal instruments: The National People's Congress could enact a law conferring on local governments the power to levy a tax on real property. ${ }^{104}$ Although this solution is politically challenging, we argue below that it is also politically feasible.

The property tax solution is economically obvious: A property tax would give local officials a revenue incentive to put out the welcome mat for newcomers, because growth would pay its own way. In effect, a property tax, coupled with local governments' already broad power to regulate land use, behaves as a user fee, in which new

102. See, e.g., Ren Wei, China's Grey-Area For Property Buyers: Homeowners Face Doubts Over Renewing Land-Use Leases, S.CHINA MoRNING POST (Apr. 19, 2016, 12:10 AM), http://www.scmp.com/news/china/economy/ article/1936991/chinas-grey-area-property-buyers-homeowners-face-doubts-over (discussing public concern over land-use rights in Wenzhou and the call for a clear legal framework); Stuart Leavenworth \& Kiki Zhao, In China, Homeowners Find Themselves in a Land of Doubt, N.Y. TIMES (May 31, 2016), http://www.ny times.com/2016/06/01/business/international/in-china-homeowners-find-them selves-in-a-land-of-doubt.html?_r=0 (discussing the uncertainty and unease with potential government fees connected with the sales of land or renewal of leases); Lucy Hornby, China Lease Expiries Prompt Property Rights Angst, FIN. TIMES (May 2, 2016), https://next.ft.com/content/952be9a4-0abe-11e6-b0f1-61f222853ff3 (discussing the plan to charge property owners fees in order to renew residential leases).

103. According to Article 8 of the Legislation Law, such a property tax can be legislated only by the NPC or NPC Standing Committee. See ZHONGHUA RENMIN GONGHEGUO LIFA FA (中华人民共和国立法法) [THE LEGISLATION LAW OF THE PEOPLE's REPUBLIC OF CHINA].

104. See id. 
migrants receive the benefit of local public goods only if they pay their share of those goods' average cost. ${ }^{105}$ So long as the goods are not congested by additional users, old-timer residents should welcome the revenue that the newcomers bring.

The property tax solution is also normatively attractive because it would mobilize homeowners into monitoring local affairs to ensure their money is properly spent. By making more visible the cost of governmental services, property taxes would force local cadres to justify those costs. ${ }^{106}$ By making public expenditure more visible, the property tax can give property owners incentives to review local governments' spending. The "sunshine budget" reform experiment in Wenling City of Zhejiang Province testifies to the power of visibility: This experiment granted members of people's congresses at the township level access to budget review and revision, resulting in fierce debate and veto of the government's budget plan. ${ }^{107}$ Moreover, local leaders seeking to raise property taxes for new projects will have an incentive to assuage local homeowners with opportunities to review budgets and comment on expenditures. ${ }^{108}$ Once the property tax becomes the main source of local governments' revenue, the English history as described in Douglas North and Barry Weingast's "constitution and commitment" can be repeated in China. ${ }^{109}$

105. See Bruce W. Hamilton, A Review: Is the Property Tax a Benefit Tax?, in Local Provision of Public Services: The Tiebout Model After TwentYFIVe YeARS 85, 103-04 (George R. Zodrow ed., 1983); Bruce W. Hamilton, Zoning and Property Taxation in a System of Local Governments, 12 URBAN STUD. 205 (1975) (arguing property tax is an efficient tax for public service); see also William A. Fischel, Homevoters, Municipal Corporate Governance, and the Benefit View of the Property Tax, 54 NAT'L TAX J. 157, 157 (2001) (arguing local property taxes are benefit taxes).

106. See JOSEPH FEwSMITH, THE LOGIC AND Limits OF POLITICAL REFORM IN CHINA 34-38 (2012) (noting that experiments in local elections were driven, in part, by the need to raise revenue through the direct route of taxes rather than through the indirect financing through the governmental marketing of peasants' grain). "In this way," Fewsmith notes, "the costs of village government, previously hidden, became very visible, and peasants resisted paying the taxes to cadres."

107. Chen Zhouxi (陈周锡), Wenling Jiceng Minzhu Shiyan Shengii (温岭基 层民主实验升级)，JINGJI GUANCHA BAO（经济观察报）(Mar. 14，2008), http://www.eeo.com.cn/eeo/jjgcb/2008/03/17/94144.shtml.

108. In the past decade, public participation has been adopted in many Chinese local governments regarding public utilities (water, gas, etc.) and urban planning. Analogous interests in winning public buy-in can drive local governments to promote public participation on revenues and expenditures derived from taxation.

109. See Douglass C. North and Barry R. Weingast, Constitutions and Commitment: The Evolution of Institutions Governing Public Choice in 
For all of its economic and normative appeal, however, the property tax solution is politically tricky, because property taxes have historically inspired popular resentment and even mass incidents. The agricultural tax was abolished in 2007 in large part because of farmers' resistance. ${ }^{110}$ Recent narrow experiments with property taxes in Chongqing and Shanghai have yielded insubstantial revenue and exempted most property. ${ }^{111}$ Circumstantial evidence suggests that the CCP leadership has been concerned with the political risk while agreeing on the desirability of property tax. ${ }^{112}$ The Chinese Minister of Finance said recently "property tax reform is a conundrum . . . but has to be done discarding hesitation." 113

Nevertheless, we believe that broad authorization for property taxes is now politically feasible, because property tax burdens are a more predictable and more elastic source of revenue than ground lease rents. As ground leases expire in cities across China, whether and how such leases can be renewed will become increasingly important. As the controversy surrounding Wenzhou's charging of stiff fees to renew such leases indicates, homeowners dislike the unpredictability of these rents. ${ }^{114}$ As noted above, such ground leases are an inelastic instrument for raising revenue; the local government is forced to cover a multi-decade period of expenditures with a single, large lump-sum amount of rent. Why not,

Seventeenth-Century England, 49 J. ECON. HISTORY 803, 803 (1989) (describing how structural developments in governmental wealth post-Glorious Revolution allowed the English to focus on the maintenance of property rights).

110. See John James Kennedy, From the Tax-For-Fee Reform to the Abolition of Agricultural Taxes: The Impact on Township Governments in NorthWest China, 189 ChINA Q. 43, 43 (2007); Shitong Qiao, Governing the PostSocialist Transitional Commons: $A$ Case from Rural China, 24 Colo. J. INT'L ENVTL L. \& POL'Y, 117, 130 (2013) (describing rural discontent amongst farmers in Chinese society post-socialist economic structure); see also Lu Xiaobo, The Politics of Peasant Burden Reform in China, 25 J. PEASANT STUD. 113, 117-21 (1997) (providing details about agricultural tax burden and rural resistance in China).

111. See ASIAN DEVELOPMENT BANK, supra note 100 (describing the importance of land sales to Chinese government revenue).

112. See Lou Jiwei: Yiwufangu Tujjin Fangdichan Shuizhi Gaige (楼继伟 : 义无反顾推进房地产税制改革) [Lou Jiwei, Pushing Forward Real Estate Tax Reform Without Hesitation], XINHUA WANG (新华网) (July 24, 2016), http://news.xinhuanet.com/fortune/2016-07/24/c_129172837.htm.

113. See id.

114. See Stuart Leavenworth \& Kiki Zhao, In China, Homeowners Find Themselves in a Land of Doubt, N.Y. TIMES (May 31, 2016), http://www.ny times.com/2016/06/01/business/international/in-china-homeowners-find-them selves-in-a-land-of-doubt.html?_r=0. 
then, trade the right to charge high fees for ground lease renewal for the right to impose property taxes? From the lessee's point of view, the trade would allow them to amortize their rent over many years by making quarterly or annual property tax payments rather than a single up-front rent payment. Moreover, precisely because they are levied for shorter intervals of time, lessees have more opportunities to contest the amount of taxes, demanding equivalent returns in services. To sweeten the pot for homeowners, the National People's Congress could make a local government's authority to impose property taxes contingent on the assurance that no further fees or rents, beyond the property tax, would be imposed on lessees as a condition for renewing a ground lease, eliminating the uncertainty of title from which ground lessees suffer in a system of multi-decade renewals. Moreover property-related taxes now paid by real estate developers actually constitute fifty to sixty percent of property prices and are thus paid indirectly by property buyers. ${ }^{115}$ Replacing these fragmented property-related taxes with a uniform property tax therefore would not increase the burden of property buyers but instead make their contribution to the government finance more visible, giving them more leverage in urban governance. ${ }^{116}$

In short, ground leases' gradual expiration across dozens of Chinese cities provides a golden, once-in-a-generation opportunity for the National People's Congress to replace an inelastic, politically contentious, and unpredictable source of revenue with a system of property taxation. It would allow local officials to compete with each other on their ability to cut tax burdens as well as provide services.

\section{B. The Problem of Excessive Size}

Related to the problem of local governments' limited fiscal instruments is the problem of local governments' excessive size. A relatively tiny number of local governments have final and pervasive power over immense amounts of land, making it difficult for any homebuyer to practically shop among competing providers of local public goods. Such territorially immense local governments effectively operate as local monopolies, extracting locational rents from homebuyers who, because of employment and family ties, cannot exit

115. See Chen Shaoying (陈少英), Lun Woguo Wuyeshui de Lifa Mubiao (论 我国物业税的立法目标) [On Legislative Objectives of Real Estate Tax in Our Country], 74 EASTERN CHINA UNIV. POL. SCI. \& L.J. (2011), http://article.china lawinfo.com:81/article_print.asp?articleid=61964.

116. See id. 
an entire metropolitan area in order to seek a better deal from another local government. As with the limits on fiscal instruments, however, there is a politically palatable fix well within the pale of Chinese political traditions- the fix of a federated city.

\section{Chinese Cities as Leviathans:}

\section{The Costs of Unified Metro Government}

A brief overview of local governments in a single province illustrates the vastness of the territory governed by Chinese cities. The province of Guangdong, for instance, contains 108 million residents ${ }^{117}$ but only twenty-one sub-provincial cities. ${ }^{118}$ Its capital city, Guangzhou, has eleven urban districts each of which governs over one million in population on average but are simply subsidiaries of the city government lacking independent zoning power. ${ }^{119} \mathrm{By}$ contrast, New York State, with a population roughly one and a half times the size of Guangzhou City, ${ }^{120}$ contains within its borders 932 towns, 551 villages, and 62 cities. ${ }^{121}$ There are forty-eight towns, cities, and villages in Westchester County alone, all of which are within a practical commuting distance of New York City. ${ }^{122}$ Each of these local governments can make independent decisions about zoning, expenditures, and taxation levels. ${ }^{123}$

117. See Guangdong Sheng 2015 Nian Quanguo 1\% Renkou Chouyang Diaocha Zhuyao Shuju Gongbao (广东台 2015 年全国 $1 \%$ 人口抽样调查主要数据 公报) [Guangdong Province National Population 1\% Sampling Survey Statistics], GUANGDONG BUREAU OF STAT. (MAY 11, 2016), http://www.gdstats.gov.cn/ tjzl/tjgb/201605/t20160511_327841.html.

118. Gaikuang (概况) [General Information], PEOPLE's GoverNMENT OF GUANGDONG PROVINCE (Jan. 21, 2016, 10:05 AM), http://www.gd.gov.cn/ gdgk/sqgm/201501/t20150121_208192.htm.

119. 2015 Nian Guangzhou Shi Renkou Guimo ji Fenbu Qingkuang (2015 年广州市人口规模及分有情况), GUANGZHOU SHI TONGJI JU RENKOU CHU (广州市统计局人口处) (Apr. 12, 2016), http://www.gzstats.gov.cn/tjyw/201604/t2016 0412_39495.htm.

120. See U.S. Census Bureau, Quick Facts: New York, http://www.census.gov/quickfacts/table/PST045215/36 (last visited Feb. 5, 2017) (providing data on the population of New York state).

121. N.Y. DeP'T OF STATe, DIV. OF LOCAL Gov'T SERV., What Do Local Governments Do?, http://www.dos.ny.gov/lg/localgovs.html (last visited Feb. 5, 2017).

122. Evan Bindelglass, This Graph Pits the Suburbs Against NYC, Commute Times, CURBED N.Y. (Dec. 5, 2015, 10:15 AM), http://ny.curbed.com/ 2015/12/5/9894192/this-graph-pits-the-suburbs-against-nyc-via-commute-times.

123. N.Y. DEP'T OF STATE, DIV. OF LOCAL GOV'T SERV., supra note 121. 
Each of these large Chinese cities controls the entire economy of a metropolitan area where many mutually dependent businesses congregate to take advantage of "agglomeration economies"- that is, the benefits of locating near similar businesses. ${ }^{124}$ Such businesses and their employees cannot freely shop among metropolitan areas for the best providers of public services, because some areas have built-in advantages-inherent "endowments" in Cai and Treisman's phrase-that defeat rival jurisdictions' efforts to attract investment through superior governance. ${ }^{125}$ If local officials were promoted based on their success in increasing the price of housing, then local officials controlling such immense quantities of real estate would have incentives to behave like Brennan and Buchanan's "leviathans" rather than like competitive businesses: They would extract locational rents from captive land buyers by reducing housing supply. ${ }^{126}$ The price of housing might increase in such a jurisdiction, but such an increase would reflect deadweight costs of frustrated demand rather than social benefits, as workers would be deterred by governmental policy from migrating to the areas where their labor is most productive. The demand for land within such immense jurisdictions is predictably price-inelastic because, for many households, there are few adequate substitutes for land in the metropolitan area. Economists have long argued that the inelasticity of supply of local governments insures that pure citizen mobility can never fully replace citizen voice. ${ }^{127}$ The large physical size and arguable under-population of Chinese cities suggests that this theoretical objection to foot-voting has practical application in China.

124. For an overview of the idea of "agglomeration economies," see MASAHISA FUJITA, ET AL., THE SPATIAL ECONOMY: Cities, REgIONS, AND INTERNATIONAL TRADE 1 (1999); EDWARD L. GlaESER, Cities, AGGLOMERATION AND SPATIAL EQUILIBRIUM 116 (2008).

125. See Cai \& Treisman, supra note 82, at 828 (noting that "poorly endowed units, knowing that they will lose [in the competition for investment], simply give up").

126. On the idea that non-competitive governments engage in predatory behavior, see generally GEOFFREY BRENNAN \& JAMES M. BUCHANAN, THE POWER to TAX: ANALYTICAL FOUNDATIONS OF A Fiscal CONSTITUTion (2006); Qiao, supra note 99 (describing how Chinese cities use their control over the conversion of rural land to urban use as a device to reduce the supply of land and thereby maintain higher land prices).

127. For an economic model showing that politics must supplement mobility where the supply of local governments is inelastic, see Dennis Epple \& Allan Zelenitz, The Implications of Competition Among Jurisdictions: Does Tiebout Need Politics?, 89 J. OF POL. ECON. 1197, 1216 (1981). 
The obvious solution to the problem of excessive size is to delegate land-use planning powers to smaller scale units of local government that can be clustered into a single metropolitan area. ${ }^{128}$ Assuming a transportation network that permits employees of business in the area to live within any of these local governments and commute to work, no household in such a governmentally-fragmented urban area would ever be forced to choose between the benefit of higher wages and the benefit of better public services. The result would be that households tied by employment or family to a particular commutershed could nevertheless shop among dozens of competing providers of local public goods. As discussed above, a couple who work in New York City can choose where to live among forty-eight towns, cities, and villages in Westchester County alone. None of these tiny governments control enough land to increase housing prices by restricting supply.

Extreme decentralization of zoning and taxing authority, however, is hardly a panacea. Because tiny local governments cannot capture the benefits of regulatory programs that extend throughout a commutershed, local officials in charge of those governments tend to neglect those programs. Again, Westchester County provides an illustrative case. The individual towns and villages within Westchester County zone their residential land primarily for single-family detached houses, excluding multi-family housing affordable for working class families. ${ }^{129}$ Although local governments may have several motives for such exclusion of affordable housing, one is fiscal: Property taxes levied on multi-family housing often do not cover the costs of educating the children residing in such

128. See infra note 143 and accompanying text for information about pilot programs.

129. See Sam Roberts, Westchester Adds Housing to Desegregation Pact, N.Y. TIMES (Aug. 10, 2009), http://www.nytimes.com/2009/08/11/nyregion/ 11settle.html (describing exclusionary zoning practices, such as setting minimum lot sizes, discouraging higher-density developments, and using vacant property for non-housing purposes that resulted in a federal lawsuit and ultimately a consent decree through which the county committed to challenge these village and town zoning practices and build 750 units of affordable housing over seven years); Mark Lungariello, Westchester Still Segregated Despite Lawsuit, Group Says, LOHUD (May 13, 2016, 5:31 PM), http:/www.lohud.com/story/news/local/westchester/ 2016/05/13/adc-affordable-housing/84285490/ (reporting that many communities in Westchester County continue to have exclusionary zoning laws that amount to a failure to comply with the requirements of the consent decree). 
housing. ${ }^{130}$ Affordable housing is beneficial to industrial and commercial employers who need to attract employees with affordable rents, and commercial and industrial uses often generate tax revenue in excess of the costs of services. The local governments that do not host the industrial or commercial uses, however, have no power to tax those uses to cover the costs of educating the employees' children. ${ }^{131}$ In effect, local governments in Westchester County face a collective action problem. Each government wants to host and tax non-residential uses that depend on affordable housing that they would prefer to be hosted by other jurisdictions. ${ }^{132}$

In choosing local governments with the right physical size, therefore, Chinese law-makers face a dilemma. ${ }^{133}$ If the local governments are too physically large, they will create a "leviathan effect" by extracting locational rents rather than competing for new residents, but, if they are too small, they will not capture the benefits of the uses that they regulate. ${ }^{134}$ Extremely large territories relative to population, soaring urban property prices, and under-populated

130. See, e.g., Katia Brener, Note, Belle Terre and Single-Family Home Ordinances: Judicial Perceptions of Local Government and the Presumption of Validity, 74 N.Y.U. L. REV. 447, 464 (1999) (describing local governments as motivated to pass exclusionary zoning laws to protect home and family).

131. Id.

132. Roderick M. Hills, Jr., Saving Mount Laurel?, 40 FordHAM URB. L.J. 1611, 1617-19 (2013).

133. Following Mancur Olson, supra note 38, this dilemma can be characterized as the "dilemma of fiscal equivalence," with fiscal equivalence standing for a matching of the obligation to raise revenue with the right to spend such revenue. See Roderick M. Hills, Jr., Federalism and Public Choice, in RESEARCH HANDBOOK ON PUBLIC ChOICE AND PUBLIC LAW 207, 208-09 (Daniel Farber \& Anne Joseph O'Connell eds., 2010) (describing Mancur Olson's "dilemma of fiscal equivalence").

134. For literature suggesting the ambiguous effects of fragmenting metropolitan areas among many local governments, see George W. Hammond \& Mehmet S. Tosun, The Impact of Local Decentralization on Economic Growth: Evidence from U.S. Counties, 51 J. REGIONAL SCI. 47, 48 (2011) (finding that fragmentation increases economic growth in metropolitan but not non-metropolitan counties); Arthur C. Nelson \& Kathryn A. Foster, Metropolitan Governance Structure and Income Growth, 21 J. URB. AFF. 309, 319 (1999) (finding that the presence of a metropolitan government improved income growth in fragmented urban areas), Dan Stansel, Local Decentralization and Local Economic Growth: A Cross-Sectional Examination of US Metropolitan Areas, 57 J. URB. AFF. 47, 62-65 (2004) (finding negative relationship between the central-city share of metro area population and economic growth and a positive relationship between both the number of municipalities per 100,000 residents and the number of counties per 100,000 residents and economic growth). 
Chinese cities all suggest that, in China, the "leviathan" effect predominates. ${ }^{135}$ The question remains whether the Chinese system of local government can be reformed in a politically feasible way to successfully balance these rival risks.

\section{The Solution of the Federated City}

We suggest that China's current multi-layered system of local government provides the CCP leadership with ample opportunities to experiment with what we call "the federated city," a metropolitan organization that can simultaneously avoid the leviathan effect and still capture regional economies in the production of laws and infrastructure. Our basic proposal is that sub-city governments ought to be given more functionally specialized taxing, spending, and regulatory powers that are tailored to their geographic scope. Urban districts embedded in cities, for instance, ought to have the power to tax land in their territory to finance the infrastructure and regulation that primarily benefits district land. The larger city, in turn, ought to have primary responsibility for infrastructure that benefits the entire region. On this division of responsibilities, Pudong District, a subdivision of Shanghai, would be responsible for imposing taxes on its own real estate to finance Century Park, the 140-hectare park located in Pudong's new area, because it is likely that the park will only increase the value of land located in Pudong itself. By contrast, the Shanghai government would be responsible for financing Pudong International Airport, because the entire region is served by such large-scale transit infrastructure.

Is such a suggested reform of metropolitan government politically feasible in China? Debates about the proper scale of local government in China are hardly novelties, dating back to at least the Qing Dynasty, when the emperor rejected the creation of townships for fear that they would add to residents' tax burden. ${ }^{136}$ More recently (between 1983 and 1997), China has experimented with allowing counties to apply to become "county-level cities" ("CLCs") with greater access to revenue and regulatory powers than ordinary counties. ${ }^{137}$

135. On the under-population of China's cities, see Au \& Henderson, supra note 96 , at $571-72$.

136. See William T. Rowe, China's LAST EMPIRE: The Great QING 50 (2009) (describing emperor's rejection of proposals in the 1720 s to create township-level government below the traditional county magistracies).

137. See Shenggen Fan et al., Challenges of Creating Cities in China: Lessons From a Short-Lived County-to-City Upgrading Policy, 40 J. COMP. ECON. 
The central authorities abandoned the creation of new CLCs in 1997, perhaps motivated by the absence of evidence that CLCs actually outperformed ordinary counties ${ }^{138}$ and also by the additional costs that such CLCs imposed on the central government. ${ }^{139}$ There is, however, little doubt that the Chinese leadership has the political will to experiment with delegations of greater powers to smaller units. ${ }^{140}$ The political feasibility of such a reform might increase to the extent that the newly empowered units are expected to pay their own way with their own tax revenue.

Would devolution of power to smaller units improve metropolitan governance? There is circumstantial evidence that prefectural-level cities' productivity increases if they contain more than a single urban district, with the benefits peaking at three districts per city with 1.28 million residents. ${ }^{141}$ It is difficult, however, to assess the relative performance of unified versus fragmented metropolitan areas in China, because China has not delegated the sort of broad regulatory or taxing powers that we recommend to the subdivisions of cities. ${ }^{142}$

In the absence of firmer evidence, pilot programs are needed in order to test the benefits and costs of fragmentation. Facilitating foot-voting requires some strengthening of sub-city units to enable citizens to shop within a single metropolitan area, but Chinese reformers are already experimenting with such devolution. ${ }^{143}$ Such a

$476,478-80$ (2012) (describing the process by which counties could enlarge their powers by becoming county-level cities).

138. See id., at 489 .

139. See Li Lixing, The Incentive Role of Creating "Cities" in China, 22 CHINA ECON REV. 172, 174-75 (2011).

140. See infra note 143 and accompanying text for pilot programs.

141. See Bindong Sun, Tinglin Zhang, Yinyin Cai, \& Rui Wang, Government Fragmentation and Metropolitan Economic Performance: Evidence from China 9 (UCLA Ziman Center for Real Estate Working Paper, 2014), http://www.anderson.ucla.edu/Documents/areas/ctr/ziman/2014-06WP.pdf.

142. See Jae Ho Chung and Tao-chiu Lam, China's "City System" in Flux: Explaining Post-Mao Administrative Changes, 180 CHINA Q. 945, 958 (2004) (arguing urban districts do not constitute a level of fiscal authority). The urban districts are otherwise delegated a wide range of responsibilities including judicial and civil administration, public health and security, industry and commerce, education, and cultural issues. See Him Chung, State Regulation and China's Administrative System: A Spatial Perspective, 8 CHINA REv. 201, 225 (2008).

143. In 2015, for instance, the National Development and Reform Commission promulgated a plan to experiment with township-level cities in Dongguan to grant more autonomy to township governments in the city. See "Che Zhen Jian Shi” Dongguan Xian Shi dui Zhongshan Youhe Qishi? (“撒镇设市”东党 
devolution need not result in undersized urban districts imposing external costs on their neighbors or neglecting externally beneficial infrastructure, because cities in which these subunits are embedded could pick up the regional slack. In particular, tax revenue from large-scale businesses employing commuters from the entire region could be redistributed to those urban districts that provide housing and services, such as schools for workers at such enterprises. This would avoid the collective action problem confronted by small local governments competing for business but shun the housing needed to attract workers.

\section{Reforming Hukou to Facilitate Foot-Voting}

The power of Chinese citizens to vote with their feet is limited by China's household registration system (hukou, 户口). Inhabitants without hukou do not get the benefits of local medical, educational, and other social services provided by the local government. ${ }^{144}$ To what extent are such impediments to free mobility an obstacle to the sort of foot-voting that we defend?

\section{The Obstacle of Hukou to Foot-Voting}

There is no doubt that hukou poses a major obstacle to Chinese citizens' foot-voting. It is a paradox that the more migrants a city attracts, the more reluctant a city government is to open its social welfare system to such migrants. Beijing, Shanghai, Shenzhen and Guangzhou-all Chinese mega cities and economic engines that are the most popular destinations for migrant populations-are also the most aggressive in strictly limiting their schools and social security systems to people with hukou. ${ }^{145}$ Although the central government

先试对中山有何㞋示?) [Replacing Townships with Cities First Experimented in Dongguan: What's the Lesson for Zhongshan?, PEOPLE (Feb 12, 2015), http://cpc.people.com.cn/n/2015/0212/c87228-26551285.html.

144. See, e.g., Mingqiong Zhang et al, The Institution of Hukou-based Social Exclusion: A Unique Institution Reshaping the Characteristics of Contemporary Urban China, 38 INT'L J. OF URB. \& REG'L RES. 1437, 1443 (2014) (finding that rural towns discriminate against migrant workers in denying benefits associated with hukou).

145. Quanguo Zuinan Na Hukou de Shige Chengshi: Ruhu Nandu he Fangiia Cheng Zhengbi (全国最难拿户口的十个城市：人户难度和房价成正比) [The Top Ten Cities Measured by the Difficulty of Receiving Hukou: Positive Correlation between Housing Prices and Difficulty in Receiving Hukou], MEIJING WANG (每经网), May 16, 2016, http://www.nbd.com.cn/articles/2016-0516/1005283.html. 
has pushed hukou reform across the country, it has accommodated the largest cities' desire to exclude persons without hukou, adopting instead the policy of "open[ing] the hukou system in towns and small cities comprehensively, open[ing]] the hukou system in medium-size cities orderly, in big cities reasonably, and strictly control[ling] the population of especially big cities." 146 The State Council has defined "especially big cities" as cities with more than five million in population, ${ }^{147}$ which would exclude essential reforms in most of the fast-growing cities. The number of people excluded from local services by the hukou system is staggering, constituting huge percentages of the residents in China's "mega-cities." 148

Without an effective mechanism by which cities can charge migrants with the costs of the services that these migrants consume, city mayors view the migrant population as a pure burden. ${ }^{149}$ Lacking a direct and simple way to tax residential development, local officials rely on a complex formula for awarding hukou to migrants likely to add to a city's economic productivity and not burden city services. Despite some differences in details, Chinese mega cities have granted hukou to migrants based on education, wealth, skills, and

146. Zhonggong Zhongyang guanyu Quanmian Shenhua Gaige Ruogan Zhongda Wenti de Jueding (中共中央关于全面深化改革若下重大问题的决定) [The CCP Central Committee Decision on Several Important Issues of Comprehensively Deepening Reform], XINHUA WANG (新华网), Nov. 12, 2013, http://news.xinhuanet.com/politics/2013-11/15/c_118164235.htm.

147. Guowuyuan (国务院) [State Council], Guanyu Jinyibu Tuijin Huji Zhidu Gaige de Yijian (关于进一步推进户籍制度改革的意见) [Opinions on Pushing Hukou Reform Forward] (Jul. 30, 2014), http://www.gov.cn/zhengce/content/201407/30/content_8944.htm.

148. Among the 13.5 million population in Guangzhou, only 8.5 million have hukou; among the 23 million population in Beijing, only 13 million have hukou; among the 24 million population in Shanghai, only 14 million have hukou; among over 12 million population in Shenzhen, only three million have hukou. See Qunian Guangzhou Huji Renkou wei Jin Sannian lai Zuigao (去年广州户籍人 口为近三年来最高) [Last Year Population with hukou in Guangzhou the Highest in Recent Three years], IFENG (Apr. 14, 2016), http://news.ifeng.com/a/20160414/ 48450684_0.shtml.

149. See, e.g., Chen Renze (陈仁泽), Teda Chengshi, Renkou Nenggou Kongzhi ma? (特大城市, 人口能够空制㐷? ) [Can We Control Population in Mega Cities?], RENMIN WANG (人民网) (Sep. 27, 2013), http://finance.people.com.cn/ n/2013/0927/c1004-23051143.html (arguing that the current mechanisms for dealing with the imbalance of resources resulting from the surge of migrants, such as prohibiting "group renting" and limiting purchases, are short-sighted and will create new problems down the way). 
youthfulness. ${ }^{150}$ The essentially fiscal character of hukou is revealed by the bonus points awarded to outside investors who create more than a certain number of job opportunities and pay above a certain amount of taxes. ${ }^{151}$

Concededly, some sort of link between revenues and expenditures is necessary not only for economic efficiency, but also for foot-voting democracy. ${ }^{152}$ In order to cast an intelligent "foot-vote" on both expenditures and revenue generation, citizens' choice of a jurisdiction as their residence must trigger not only the right to receive local benefits but also the obligation to pay for those benefits. Otherwise, migration does not reveal that the citizen values the benefit at its cost of production. Given the limits on local taxing powers, the hukou-awarding system in big Chinese cities is actually quite rational as a way of matching revenues and expenditures. But a mechanism like Shanghai's that rates migrants by a complex mix of demographic, economic, and educational factors is a much more crude mechanism by which to assess migrants' willingness and ability to pay, resulting in the exclusion of many potential citizens from receiving services who might be willing and able to pay for them.

Whether a migrant worker would contribute to a city economy sufficiently to cover the costs of local services that the migrant receives should be decided on a far simpler basis-whether he or she has a job, the wages of which suffice to cover the costs of the services that he or she receives. If there is demand for the migrant's labor within a jurisdiction that is sufficient to cover both the public and private costs of the migrant's working in that jurisdiction, then why should the city government deter the migration by withholding local services? One need not (and we do not) endorse the view that cities

150. The four main sections of the Shanghai hukou point-accumulation system (积分落户制度) are age (the younger the better), education (the more educated the better), expertise and professional skills (the higher the better), and length of time paying social security in Shanghai (the longer the better). See 2016 Nian Shanghai Jifen Luohu Zhidu Xize (2016 年上海积分溚户制度细则) [2016 Shanghai Detailed Rules of Point-Accumulation System of Receiving Hukou], SHANGHAI HUKOU WANG (上海户口网), http://www.hukoushanghai.com/ shhkxzc/550.html.

151. See id.

152. For a concise statement of the argument that economic efficiency requires that local governments generate from their own residents the revenue that they spend on those residents, see RICHARD MUSGRAVE, Combining and Separating Fiscal Choices: Wicksell's Model at its Centennial, in PUBuIC FINANCE IN A DEMOCRATIC SOCIETY: VOLUME III THE FOUNDATIONS OF TAXATION AND EXPENDITURE 81, 99-101 (2000). 
will inevitably reach their optimal population through private migration decisions as long as migrants pay the average cost of the public services that they consume. ${ }^{153}$ The justification for restricting city size, however, should be rooted in some specific analysis of a market failure in private locational decisions, not in local governments' arbitrarily limited choice of fiscal instruments. The challenge of hukou reform is to figure out how local governments can more directly charge migrant workers for the costs of the local public services that they consume as a result of their decision to migrate.

\section{Reforming the Hukou System through Broader Fiscal Instruments and Federative Local Governments}

We urge that hukou within a jurisdiction be based exclusively on the migrants' purchase or rental of real property in the jurisdiction providing the service for which hukou is sought. Our proposal for hukou reform, however, is contingent on the adoption of our two previous recommendations for the broadening of smaller local governments' taxing and regulatory powers in the context of a federated metropolitan area. At its most basic level, we urge that the migrant's willingness to pay the price of renting or buying land presumptively indicates that the migration is cost-justified, just so long as local governments have broad powers to charge new migrants for the services that they consume and are small enough not to act as little leviathans, extracting locational rents by restricting housing supply. Further refinements of migration incentives, as we suggest below, can be managed by the federated metropolitan areas described and defended in Part IV(B)(2) above.

Our proposal does not eliminate hukou. Under our proposal, cities can still withhold services from citizens who neither rent nor buy real estate within the service-providing jurisdiction. In this

153. The question of whether and under what conditions free migration results in optimally populated cities is a complex one. Under reasonable assumptions, "competition neither leads to, nor sustains, cities of optimal size." Arnott \& Stiglitz, supra note 67 , at 498 . For an argument that migration leads to excessively populated cities because migrants pay only average costs rather than marginal costs of their migration, see George Tolley, The Welfare Economics of City Bigness, 1 J. URB. AFF. 324, 324 (1974). For an argument that certain cities' locational advantages and incentive effects of national taxes lead to suboptimally small cities, see David Albouy \& Nathan Seegert, The Optimal Population Distribution across Cities and the Private-Social Wedge 1 (Working Paper 2010), http:/homedev.business.utah.edu/u0908787/papers/OptimalPopulationDistributio nacrossCitiesand thePrivateSocialWedge_AlbouySeegert.pdf. 
respect, our proposed form of hukou resembles the concept of "bona fide residency" in U.S. constitutional law. ${ }^{154}$ If we treat hukou as a shorthand for eligibility to enjoy the public services and urban governance provided by a particular jurisdiction, then, under our proposal, each city would have its own hukou system in which residents who own or rent an apartment in a city are "granted hukou"-that is, made eligible to receive the package of local public goods provided by the local government. The local government's power to exclude persons who have not invested in local real estate distinguishes our proposal from alternative recommendations that abandon the hukou system completely by delegating to the central government the task of guaranteeing every citizen equal access to the same "basic" public services across different local governments. ${ }^{155}$ Our justification for rooting hukou in the purchase or rental of land requires the adoption of our proposals above which call for territorially smaller local governments to exercise a broader set of taxing powers. ${ }^{156}$ If local governments can recapture the value they confer on land through their services, then the price of that land should presumptively reflect both the value of the services and the burden of the taxes needed to finance them.

Would a property-based hukou system exclude middle- and low-income populations from a city? We think not. Consider the example of so-called "left-behind children" (liushou ertong, 留守儿童). Parents seeking higher wages in a productive city where they lack hukou must leave their children behind in the village where they

154. For an explanation of how lack of "bona fide residency" is a sufficient basis under the U.S. Constitution for local governments to withhold basic educational and other local services, see Roderick M. Hills, Jr., Poverty, Residency, and Federalism: States' Duty of Impartiality Toward Newcomers, 1999 SUP. CT. REV. 277, 281-83, 288-98, 301-09, 312-26. For an example of the U.S. Supreme court's upholding a school district's exclusion of a child from its public schools because the child was not a bona fide resident of the school district, see Martinez v. Bynum, 461 U.S. 321, 332-33 (1983).

155. See Wang Ling (王羚), Huji Zhidu Gaige Tuijin Huanman Xuezhe Jianyi Gaige Jizhi (户籍制度改革推进缓慢 学者建议改革机制) [Reform of the Household Registration System has Moved Forward Slowly; Scholar Suggests Reform Mechanisms], YICAI (May 27, 2015), http://news.xinhuanet.com/ fortune/2014-07/31/c_126819302.htm(stating that the central government has the power to design the system); Kam Wing Chan, The Household Registration System and Migrant Labor in China: Notes on a Debate, 36 POPULATION AND DEv. REv. 357,361 (one stream of reform proposals is concerned with making the hukou system more "humane," for example, offering urban hukou to migrant workers' children and parents).

156. See supra part IV. B. 
have hukou so that their children can attend school. ${ }^{157}$ Such family separations can be emotionally painful and logistically difficult. ${ }^{158}$ Because migrant workers frequently rent housing where they work, our proposal would entitle them to bring their children with them.

Would local governments be incentivized to limit development density to ensure that each migrant pays the average per capita cost of local services? Because property taxes are typically levied on the value of land and improvements, landowners who squeeze more people into a less valuable structure pay less in taxes per unit of service consumed than landowners who develop land at a lower density with more valuable structures. Therefore local governments might have incentives to impose a prohibition on high-density development, a form of "fiscal zoning," thereby transforming the property tax into a benefits charge under which each resident is forced to pay a minimum tax price sufficient to cover her consumption of services like education for her children. ${ }^{159}$

We believe that the danger of fiscal zoning is mitigated by the weakness of urban districts and the supervisory role of

157. See, e.g., Lizzie Dearden, Four Siblings "Kill Themselves" After Being Abandoned by Parents in China, THE INDEPENDENT (June 13, 2015), http://www.independent.co.uk/news/world/asia/four-siblings-kill-themselves-afterbeing-abandoned-by-parents-in-china-10317720.html (explaining that the hukou system prevents migrant workers from bringing their children with them when they move to a different city for a job, as the children will lose their right to subsidized education, health care, and other basic services in the new city); John Sudworth, Counting the Cost of China's Left-Behind Children, BBC (Apr. 12, 2016), http://www.bbc.com/news/world-asia-china-35994481 (estimating that more than sixty million children in China are living away from their parents as their parents live and work elsewhere).

158. Zhang Xudong et al. (张旭东), Nongcun Liushou Ertong Cunzai de Jiuge Tuchu Wenti ji Duice Jianyi (农村留守儿童存在的九个突出问题及对策建议) [Nine Prominent Problems of "Left behind" Children and Proposed Solutions], PEOPLE (June 19, 2015), http://theory.people.com.cn/n/2015/0619/c4053127180 206.html (reporting higher rate of pyschological issues in "left behind" children).

159. For the most famous theory that set forth that the property tax becomes a benefit charge when combined with restrictive zoning, see Bruce W. Hamilton, Zoning and Property Taxation in a System of Local Governments, 12 URB. STUD. 205, 210 (1974). However, the theory has been challenged. See Peter Mieszkowski \& George R. Zodrow, Taxation and the Tiebout Model: The Differential Effects of Head Taxes, Taxes on Land Rents, and Property Taxes, 27 J. ECON. LIT. 1098, 1130-31 (1989) (arguing that only "perfect zoning" that prevented any sort of value-lowering alterations and structures would transform a property tax into a benefits charge). William Fischel has responded to this argument against the "benefit" theory of taxation. WILLIAM A. FISCHEL, ZONING RULES:: THE ECONOMICS OF LAND USE REGULATION 135-36, 142-44 (2015). 
prefectural-level cities, characteristics that avoid both "leviathan" effects and externalities. Urban districts are too small to enjoy a monopoly over an entire metropolitan area's land. They are, however, also large enough to capture many of the external benefits conferred by affordable housing on commercial, office, and industrial uses. The urban district and county, therefore, resemble what Professor William Fischel calls the "concentrated" metropolitan area. It has enough local governments to avoid "monopoly pricing" for land yet not so many that competition leads to free-riding and collective action problems that lead to the excluson of affordable housing. ${ }^{160}$ Even though current interjurisdictional competition in China focuses on investment, we have seen evidence that local governments open public services and provide residential land to increase their competitiveness. ${ }^{161}$ Moreover, we note that the devolution of taxing and regulatory power to urban districts leaves in place prefectural-level cities' powers to correct external economies between districts. In a federative metropolitan area, the prefectural-level city could be given control over business-oriented taxes imposed on industrial and commercial uses, redistributing some share of this tax revenue to districts that provide the housing and educational services needed by those employers' workers.

\section{CONCLUSION}

By promoting local officials on the basis of local land values, Chinese law could give them an incentive to cultivate allies who would protect those values on which the officials' careers rested. These allies would not be motivated by high-minded ideals of democracy and human rights but selfish and grubby preferences to safeguard their down payment. Precisely for that reason, the CCP could tolerate the sorts of participation that these foot-voters-turnedhomevoters would foster. Compared with the exercise of ballot-voting on more abstract and edifying issues, such local participation on garbage collection and school performance might seem like small potatoes. But those are the only potatoes on offer in China in the

160. William Fischel, Political Structure and Exclusionary Zoning: Are Small Suburbs the Big Problem?, in FISCAL DECENTRALIZATION AND LAND PoLICIES 111, 120-22 (Gregory K. Ingram \& Yu-Hung Hong eds., 2008).

161. See Celine Ge, Housing Crisis in China's 'Silicon Valley' Huawei, Other Hi-Tech Giants Head for Cheaper Cities as Rising Costs Deter Talent, S. ChINA MORNING POST (May 30, 2016), http://www.scmp.com/news/china/policiespolitics/article/1952617/housing-crisis-chinas-silicon-valley-huawei-other-hi. 
current regime. We suggest that such improvements, small as they are, are worth advancing, both for CCP leaders intent on promoting their own legitimacy and assuaging Weibo anger as well as for democratic reformers who would like to see a foot-voting mechanism that could imitate ballot voting.

Interjurisdictional competition has been a familiar theme in Chinese law and politics. During the Great Leap Forward from 1959 to 1961 , over thirty million people died from starvation in part because provincial leaders competed for Chairman Mao's favor by delivering ever-higher grain quotas to the central government. ${ }^{162} \mathrm{On}$ the other hand, the Chinese economic miracle in the past thirty-six years is also attributed to subnational leaders' interjurisdictional competition, this time, to attract investment capital. ${ }^{163}$ These two different stories tell us that the voice to which local officials respond crucially affects the consequence of interjurisdictional competition. Our proposal endeavors to transform competitions for the favor of supreme leaders or capital investors into competitions for the favor of the Chinese people. This would not be the final step of China's democratization, but it would nevertheless be a crucial step towards increasing local government accountability. Once local officials begin to solicit the "foot-votes" of migrants, they also will have incentives to promote internal procedures to protect those foot-voters' investments. Such procedures might logically and eventually include ballots.

The Chinese case also reveals the nuanced relationship between voice and exit. Just as we say exit is foot-voting, exit is also voice in the most essential way. Scholars have sometimes assumed away the political mechanisms by which exit converts into a plausible complement for voice. ${ }^{164}$ Neither foot-voting nor ballot-voting is a silver bullet against government unaccountability. As we show in the Chinese context, it requires proper examination of the size of local governments, the fiscal system, and the immigration system, among many other aspects of public law. Is democracy possible in China? We do not know; it depends on your definition of "democracy." But can government accountability in China be improved through household mobility? Our answer is yes.

162. Xu Chenggang (许成钢), Difang Jingzheng de Kunjing (地左竟争 的困境) [Dilemma of Local Competition], CHINA REFORMS (Sep. 1, 2011), http://www.ckgsb.edu.cn/uploads/professor/201607/15/19.pdf.

163. See Xu, supra note 66.

164. See Part II.A on this point. 